\title{
OPTIMAL INSULATION OF SOLAR HEATING SYSTEM PIPES AND TANKS
}

\author{
GeraRd F. JONES and NoAm LIOR \\ Department of Mechanical Engineering and Applied Mechanics, University of Pennsylvania, \\ Philadelphia, PA 19104, U.S.A.
}

(Received 1 July, 1978)

\begin{abstract}
A compact and time-effective insulation design procedure for solar heating system piping and water-filled thermal storage tanks was developed. Recognizing the particular sensitivity of solar systems to cost, the economic aspect of the problem was treated by a comprehensive present-value life-cycle cost analysis. In the development of the method, a numerical sensitivity analysis was performed to determine the relative effects of all relevant independent variables (within their pertinent ranges) on piping and tank heat transfer coefficient values. For the acceptable error limits of $\pm 14 \%$ for pipes and $\pm 19 \%$ for tanks, it was found that one may assume that only the nominal pipe diameter (or tank diameter), the thermal conductivity of the insulation, and the insulation's thickness have an effect on the overall heat transfer coefficient. Based on this result, design graphs and tables are presented which can be used to determine the optimal insulation thickness and type, total annual heat losses, present-value annual costs of insulation and lost heat, and overall insulation R-values. The use of the method is illustrated by calculating all the above quantities for all piping and storage tanks for the University of Pennsylvania SolaRow House. The present method provided insulation thicknesses slightly greater than those obtained by the ETI technique.

A major conclusion of the study is that the cost of insulation in solar systems is not insignificant (e.g., $\sim 15 \%$ in SolaRow), and that heat losses through insulation could amount to an important percentage of the useful solar energy collected (e.g., $24 \%$ in SolaRow). This re-emphasizes the need for a careful design of insulation in solar systems.
\end{abstract}

\section{INTRODUCTION}

When compared to the delivered energy costs for a system using conventional heat sources, the collection and use of solar heat is a costly process. Hence, the solar heat loss through solar heating system surfaces (such as pipes, thermal storage tanks, etc.) should be minimized subject to associated material and labor cost constraints. Since economics probably constitutes the major present obstacle to the widespread utilization of solar heating, it is important to include careful optimization of thermal insulation in the design procedure. This optimization is obtained by selecting principally the insulation material and thickness which give the lowest total life cycle cost of insulation material, labor, maintenance, and energy lost through the insulation. A qualitative illustration of the optimization method is shown in Fig. 1.

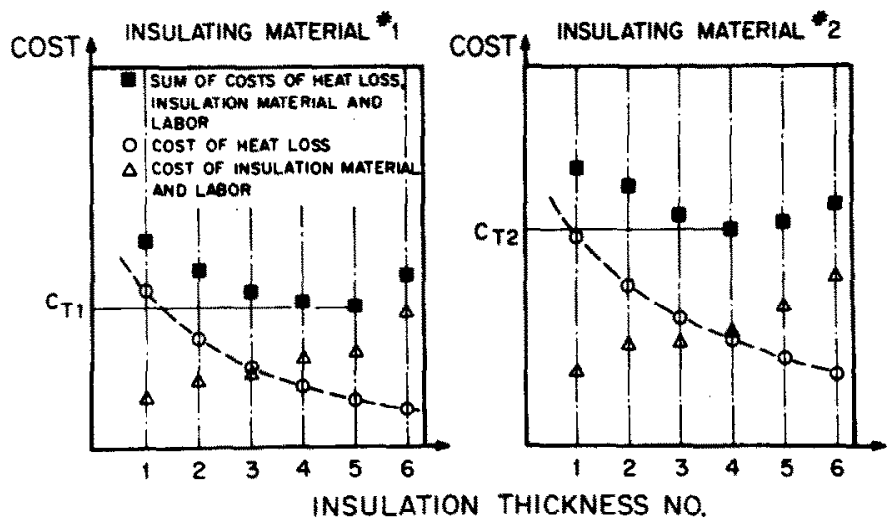

Fig. 1. Optimization of insulation thickness and material. Note: Insulation thickness increases with the "insulation thickness number". 
For a given insulating material, the amount of lost heat (and thus the cost of lost heat) decreases as the thickness of the insulation increases $\dagger$. On the other hand, the cost of the insulating material and labor increases with thickness. As the sum of these costs passes through a minimum, the optimal insulation thickness is determined. The cost vs. thickness relationship in Fig. 1 is shown in a number of discrete points instead of the customary continuous curve because commercial insulation is most often purchasable in discrete thicknesses only. In this example, insulating material No. 1 has an optimal thickness No. 5 which results in a total cost $C_{T 1}$, while material No. 2 has an optimal thickness No. 4 with $\operatorname{cost} C_{T^{2}}$. It is also noteworthy that when choosing between the two materials, No. 1 is optimal because $C_{T 1}<C_{T 2}$.

Least cost optimization as described above does not consider other insulation characteristics such as dimensional stability, flammability, water permeability, etc. These requirements must be satisfied before an insulation is considered a candidate for cost optimization.

Several techniques for the determination of optimal insulation thickness are presently available (Refs 1-3). These consist primarily of industrial computer programs and nomograms oriented to applications where conventional fuels are used. The recently developed ETI Method ${ }^{3}$ optimizes the selection of insulation based on a number of economic criteria, most notably life-cycle costing. It is gaining in popularity as more insulation is used in response to increasing energy costs and emphasis on industrial energy conservation. Typical simplifying assumptions made in these techniques are:

a. The thermal resistance due to both the fluid-to-tube heat transfer coefficient and the heat conduction through the tube wall is ignored (resistance $=0$ ).

b. The thermal resistance due to the heat transfer coefficient between the insulation's outer surface (or jacketing) and ambient air is assumed to be a constant, and thermal radiation from that surface is either constant or neglected.

c. Differences between nominal and actual diameters and wall thicknesses as applied to different types of tubes (e.g. steel, copper, plastic) do not enter into the heat loss calculation.

The third assumption not only affects the thermal resistance to heat flow from the tube, but when using design graphs, could lead to incorrect predictions of the heat transfer surface area and thus of the final thickness of insulation.

This study has two main goals: (1) analyze the sensitivity of the heat loss coefficient ( $U A$ value) to changes in its defining variables, and (2) use the most dominant of these in a combined heat transfer/economic model to construct convenient insulation design graphs and tables. With these, an optimal insulation material and thickness and the annual heat loss for each pipe and tank size for a given solar system can be determined. The analysis considers indoor water-filled storage tanks, as well as both indoor and outdoor piping for four working fluids. Influence from the following independent variables is included:

(1) Ambient temperature and wind velocity.

(2) Piping or storage tank hot fluid temperature.

(3) Piping material and nominal size.

(4) Working fluid type: Water, $50-50 \%$ (by weight) ethylene glycol-water solution, silicone liquid (Dow Corning ${ }^{\circledR}$ Q2-1132), hydrocarbon heat transfer liquid (Shell Thermia $^{(3)}$ Oil 15).

(5) Insulation thickness.

(6) Insulation thermal conductivity.

(7) Piping design pressure gradient (which determines liquid flow velocity).

(8) Insulation surface emissivity.

†That is true for above-critical diameters. For below critical ones, the addition of insulation increases the heat loss. All piping considered here is practical for solar systems and has above-critical diameters (see Section 4). 
(9) Annual system usage factor.

(10) Annual payback on capital.

(11) Cost of solar heat.

(12) Cost of insulation material, jacketing and labor.

\section{OPTIMIZATION MODEL DEVELOPMENT}

\subsection{Heat Transfer Model}

The expression for the rate of steady radial heat flow, per unit length of the cylinder described in Fig. 2, is

$$
Q_{l}=(U A)\left(T_{f}-T_{a}\right)=(U A) \Delta T
$$

with

$$
\Delta T \equiv T_{f}-T_{a}
$$

and

$$
\begin{aligned}
U A= & \pi\left\{\left[1 / d_{1} h_{i}\right]+\left[\ln \left(1+2 t_{p} / d_{1}\right) / 2 k_{p}\right]\right. \\
& \left.+\left[\ln \left(1+2 t_{i} / d_{1}+2 t_{p}\right) / 2 k_{i}\right]+1 / \gamma d_{1}\left(h_{0}+h_{r}\right)\right\}^{-1} \\
\equiv & \text { rate of heat loss per unit of pipe length per unit of } \Delta T
\end{aligned}
$$

The development of eqn (3) and the description of its different terms is detailed in Appendix A.

For indoor storage tanks where the internal tank walls are completely wetted by water and no thermal stratification is assumed, the total rate of heat transfer per tank, $Q^{\prime}$, is given by

$$
Q^{\prime}=l Q_{l}+Q_{t}+Q_{b}
$$

where $l$ is the tank height, and $Q_{l}$ is determined from (1). $Q_{t}$ and $Q_{b}$ are the heat transfer rates from the top and bottom of the tank, respectively. Assuming steady heat flow and $d_{3} / d_{1} \dagger$ not much greater than unity:

$$
Q_{t} \text { or } Q_{b}=\pi d_{1}^{2} \Delta T / 4\left[\left(1 / h_{i t, b}\right)+\left(t_{p} / k_{p}\right)+\left(t_{i} / k_{i}\right)+\left(1 / h_{o t, b}+h_{r}\right)\right]
$$

The development and description of the various terms and heat transfer coefficients used for the determination of $Q_{\imath}$ and $Q_{t}$ or $Q_{b}$ are also detailed in Appendix A.

$$
\dagger d_{i}=2 r_{i} \text { from Fig. } 2 .
$$

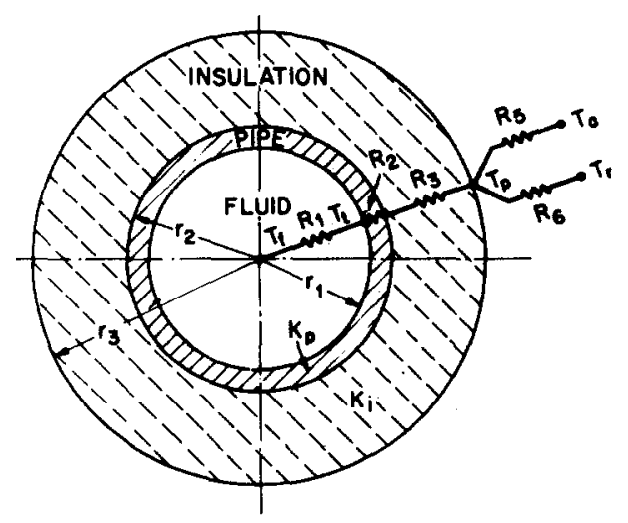

Fig. 2. The geometry and analog thermal circuit of the insulated pipe heat transfer mode:

$$
t_{i} \equiv r_{3}-r_{2}, t_{p} \equiv r_{2}-r_{1} \text {. }
$$




\subsection{The Economic Model}

A life-cycle cost analysis is employed in this study. It involves a comparison of the average annual portion of the total lifetime costs for various alternative insulation schemes. It is assumed here that the minimal life-cycle cost scheme defines the proper level of insulation. Alternative schemes for replacing the energy lost through system surfaces could have been employed. However, such schemes, including the addition of solar collectors or other heat sources, are assumed a-priori to be more costly than the addition of insulation.

Average annual costs associated with the minimal life-cycle cost scheme arise from three sources:

(1) Average annual present-value of the initial lumped investment which provided insulation labor and material.

(2) Present-value average annual maintenance costs.

(3) Present-value average annual energy costs.

The equation expressing this total present-value average cost $C_{T}(\$ / f t-y r)$ per unit length of piping insulation is

$$
C_{T}=\left[E_{1(1)} / n\right]\left(C_{i}+C_{j}+C_{l}\right)+\left[E_{2(1)} / n\right] C_{m}+8760 \times 10^{-6} F C_{S} U A\left(T_{f}-T_{a}\right)
$$

where the three terms on its r.h.s. correspond to the above items (1)-(3), respectively. In particular,

$C_{i}=$ Base cost of the insulation material, including the cost of fitting and valve insulation prorated over the straight pipe length, $\$ / \mathrm{ft}$.

$C_{j}=$ Base cost of insulation jacketing, $\$ / \mathrm{ft}$.

$C_{l}=$ Base cost of insulation labor, $\$ / \mathrm{ft}$.

The E-terms are economic coefficients for converting cash flows to present-values. They are described in Appendix B.

$C_{m}=$ Base cost of maintenance during the first year, $\$ / \mathrm{ft}$.

$F=$ Annual usage factor $(0 \leq F \leq 1)$ of the insulated component. This is the annual fraction of time during which the solar collection system (or storage tank) loses heat. Consideration must be given to the working fluid remaining in piping and exposed to ambient temperatures after the solar collection system has stopped.

$T_{f}, T_{a}=$ Average annual Farenheit temperature of working fluid and ambient respectively. These variables are assumed constant over the lifetime of the insulation.

$C_{s}=$ Present-value annual average cost of solar heat, $\$ /\left(10^{6} \mathrm{Btu} / \mathrm{yr}\right) . C_{s}$ may be a given value, or could be calculated by using the equation

$C_{s}=\left\{\left[M_{i} E_{1(2)}+M_{0} E_{3}+M_{m} E_{2(2)}\right] / \eta L_{B} n\right\}+\left[\theta(1-\eta) C_{a} E_{4} / n\right]$

where:

$M_{i}=$ Initial capital cost of solar heating system including all labor and materials.

$M_{0}=$ First year operating costs of solar heating system.

$M_{m}=$ First year maintenance cost of solar heating system.

$L_{B}=$ Total annual space heating and domestic hot water load $\left(10^{6} \mathrm{Btu} / \mathrm{yr}\right)$.

$\eta=$ Fraction of annual space heating and domestic hot water load contributed by solar energy.

$\theta=1$ or 0,1 corresponding to auxiliary heating of storage tank water directly, 0 corresponding to no direct auxiliary heating of water.

$C_{a}=$ First year cost of auxiliary energy delivered to storage $\left(\$ / 10^{6} \mathrm{Btu}\right)$.

Equation (6) can be rearranged to yield 


$$
C_{T M} \equiv C_{T} / C_{s} F\left(T_{f}-T_{a}\right)=C_{R}+U A^{*}
$$

where

$$
C_{R} \equiv\left[E_{1(1)}\left(C_{i}+C_{j}+C_{l}\right)+E_{2(1)} C_{m}\right] / n C_{s} F\left(T_{f}-T_{a}\right),
$$

and

$$
U A^{*} \equiv 8760 \times 10^{-6} U A \quad\left(10^{6} \mathrm{Btu} / \text { foot-yr- }{ }^{\circ} \mathrm{F}\right) .
$$

For thermal storage tanks, eqn (6) takes the form:

$$
\begin{aligned}
C_{T}^{\prime}=\left[E_{1(1)} / n\right]\left(C_{i}+C_{j}+C_{l}\right)+\left[E_{2(1)} / n\right] & C_{m} \\
& +8760 \times 10^{-6} C_{s} l U A^{\prime} F\left(T_{f}-T_{a}\right)
\end{aligned}
$$

and eqns $(8)-(10)$ become:

$$
C_{T M}^{\prime} \equiv C_{T}^{\prime} / C_{s} l F\left(T_{f}-T_{a}\right)=C_{R}^{\prime}+U A^{* \prime},
$$

where

$$
C_{R}^{\prime} \equiv\left[E_{1(1)}\left(C_{i}+C_{j}+C_{l}\right)+E_{2(1)} C_{m}\right] / n C_{s} l F\left(T_{f}-T_{a}\right)
$$

and

$$
U A^{* \prime} \equiv 8760 \times 10^{-6} U A^{\prime}\left[10^{6} \mathrm{Btu} /\left(\text { foot tank length)-yr- }{ }^{\circ} \mathrm{F}\right]\right.
$$

$U A$, the heat loss coefficient per unit length of insulated surface, depends on many variables and its determination complicates the insulation design procedure. Therefore, a numerical sensitivity analysis was performed to possibly reduce the number of independent variables which need to be considered in the insulation design.

\subsection{General}

\section{SENSITIVITY ANALYSIS}

In the numerical sensitivity analysis, variations in $U A$ were determined by independently perturbing each of its describing variables from a given base value. $†$ If the deviation of $U A$ by such a perturbation falls within acceptable error tolerance, $U A$ can then be considered independent of that variable for the range investigated and can be calculated with that variable fixed at its base value. Upon investigation of eqns (3), (A6), (A14), (A15) and (A16), the functional form of $U A$ can generally be written as:

$$
U A=U A\left(d_{1}, t_{i}, f_{L}, k_{p}, t_{p}, T_{a}, T_{f}, \phi, \epsilon, k_{i}, V\right)
$$

where $T_{a}$ and $T_{f}$ are included to account for temperature dependent air and working fluid thermophysical properties and for nonlinear effects of thermal radiation and natural convection.

\subsection{Piping}

Commercially available, schedule 40 carbon steel pipe and type $\mathrm{L}$ wall copper water tube are considered for piping materials in this analysis because of their common usage in residential and commercial areas. Since commercial piping is considered, $d_{1}, t_{p}$ and $k_{p} \ddagger$ cannot be specified independently. Instead, two alternate independent variables $M_{p}$ and $D$ (piping material and nominal diameter) are defined so that the value $M_{p}$ determines $k_{p}$ and the specification of both $M_{p}$ and $D$ determines $t_{p}$ and $d_{1}$. The number of independent variables is thus reduced from 11 to 10 . In addition, it is convenient to define:

$$
k^{*}=k_{i} / 0.010 \mathrm{Btu} / \mathrm{hr}-\mathrm{ft}-{ }^{\circ} \mathrm{F}
$$

†A base value is defined here as either a value which lies midway between the maximal and minimal value in the continuous independent variable's range, or an arbitrarily determined value within a discrete variable's range.

†See Fig. 2 . 


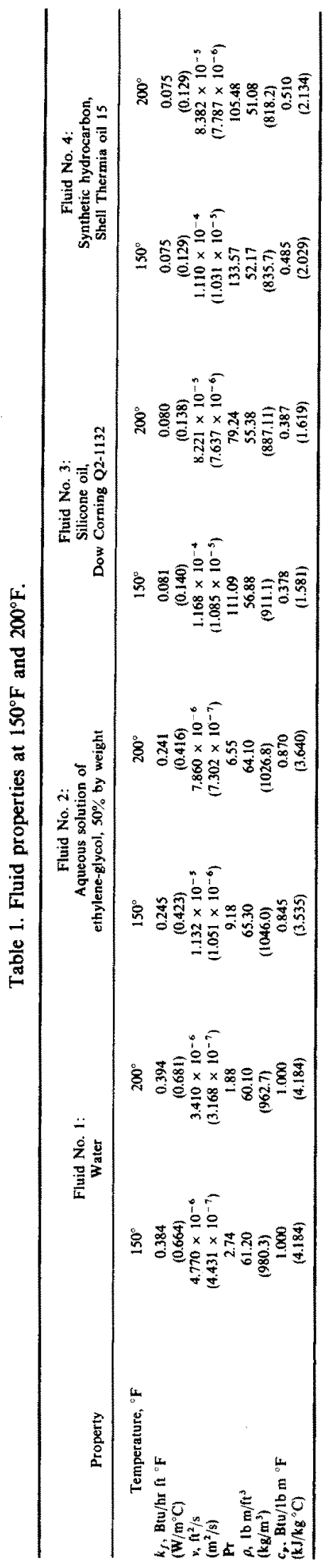


Table 2. Definition of base cases for piping insulation sensitivity analysis.

\begin{tabular}{|c|c|c|c|c|c|c|c|c|c|}
\hline \multirow{2}{*}{$\begin{array}{c}\text { Location } \\
\text { of } \\
\text { piping }\end{array}$} & \multirow{2}{*}{$\begin{array}{l}\text { Base } \\
\text { case } \\
\text { No. }\end{array}$} & \multirow[b]{2}{*}{$M_{0}$} & \multirow[b]{2}{*}{$f_{L}$} & \multicolumn{6}{|c|}{ Value of base case variables } \\
\hline & & & & $T_{f},{ }^{\circ} \mathrm{F}\left({ }^{\circ} \mathrm{C}\right)$ & $T_{a},{ }^{\circ} \mathbf{F}\left({ }^{\circ} \mathrm{C}\right)$ & $\phi$ & $\epsilon$ & $k^{*}$ & $\begin{array}{l}\mathrm{mph} \\
(\mathrm{m} / \mathrm{s})\end{array}$ \\
\hline Outdoor & $\begin{array}{l}1 \\
2 \\
3\end{array}$ & $\begin{array}{l}1 \\
2 \\
3\end{array}$ & $\begin{array}{l}1 \\
1 \\
1\end{array}$ & $\begin{array}{l}200(93) \\
200(93) \\
200(93)\end{array}$ & $\begin{array}{l}40(4) \\
40(4) \\
40(4)\end{array}$ & $\begin{array}{l}0.075 \\
0.075 \\
0.075\end{array}$ & $\begin{array}{l}0.5 \\
0.5 \\
0.5\end{array}$ & $\begin{array}{l}2.0 \\
2.0 \\
2.0\end{array}$ & $\begin{array}{l}10(4.5) \\
10(4.5) \\
10(4.5)\end{array}$ \\
\hline Indoor & $\begin{array}{l}4 \\
5 \\
6\end{array}$ & $\begin{array}{l}1 \\
2 \\
3\end{array}$ & $\begin{array}{l}1 \\
1 \\
1\end{array}$ & $\begin{array}{l}200(93) \\
200(93) \\
200(93)\end{array}$ & $\begin{array}{l}60\{16) \\
60(16) \\
60(16)\end{array}$ & $\begin{array}{l}0.075 \\
0.075 \\
0.075\end{array}$ & $\begin{array}{l}0.9 \\
0.9 \\
0.9\end{array}$ & $\begin{array}{l}2.0 \\
2.0 \\
2.0\end{array}$ & $\begin{array}{l}0 \\
0 \\
0\end{array}$ \\
\hline
\end{tabular}

Therefore, $k^{*}=1.0,2.0,3.0$ and 4.0 corresponds approximately to polyurethane foam, fiberglass or a closed cell foam rubber, foamed glass and calcium silicate insulation, respectively. The range of parameters used in the sensitivity analysis was:

\section{Discrete Design Variables}

Nominal commercial pipe diameter $D$ :

$$
\frac{3}{8}, \frac{1}{2}, \frac{3}{4}, 1,1 \frac{1}{4}, 1 \frac{1}{2}, 2,2 \frac{1}{2}, 3,3 \frac{1}{2}, 4,4 \frac{1}{2}, 5 \text { in. }
$$

Insulation thickness $t_{i}$ :

$$
\frac{3}{8}, \frac{1}{2}, \frac{3}{4}, 1,1 \frac{1}{2}, 2,2 \frac{1}{2}, 3,3 \frac{1}{2}, 4,4 \frac{1}{2}, 5,5 \frac{1}{2}, 6 \text { in. }
$$

Type of fluid $f_{L}: 1,2,3,4$, corresponding to the working fluids listed in Table 1.

Commercial pipe material $M_{p}: 1,2,3$, corresponding to copper (1), steel (2) and a hypothetical pipe material (3) which has the dimensions and thermal conductivity represented by the mean value of the commercial copper and steel materials.

\section{Continuous Value Variables}

$$
\begin{aligned}
100 \leq T_{f} & \leq 300^{\circ} \mathrm{F} \\
20 \leq T_{a} & \leq 80^{\circ} \mathrm{F} \\
0.05 & \leq \phi \leq 0.10 \\
0.10 & \leq \epsilon \leq 1.0 \\
0.010 & \leq k_{i} \leq 0.040 \mathrm{Btu} / \mathrm{hr} \mathrm{ft}^{\circ} \mathrm{F} \\
5 & \leq V \leq 15 \mathrm{mphr}
\end{aligned}
$$
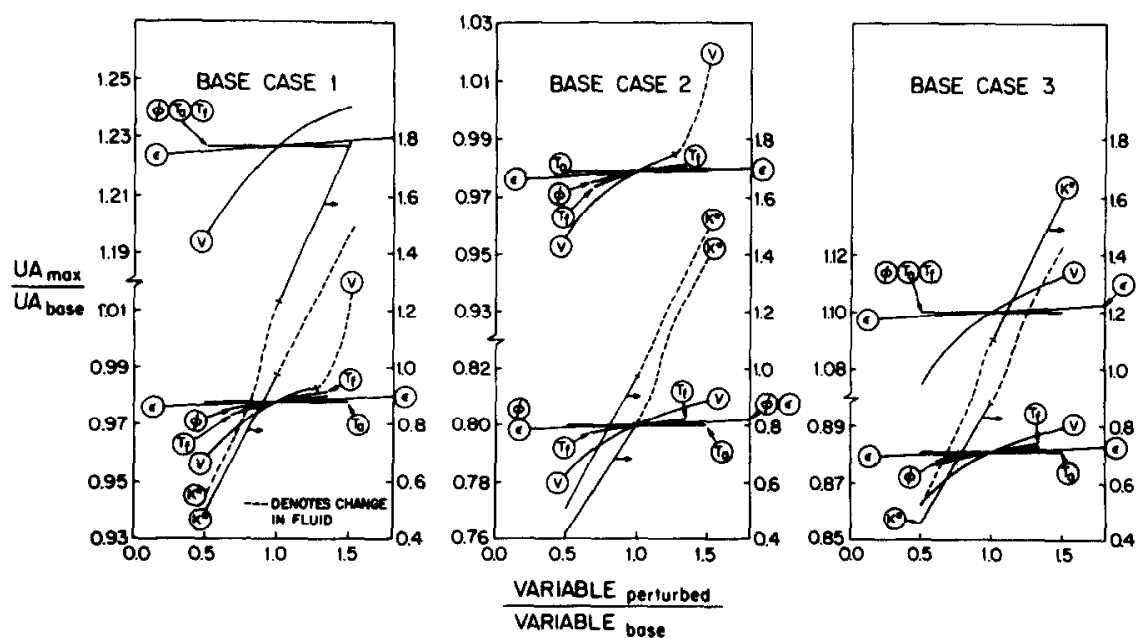

Fig. 3. Sensitivity analysis results for outdoor piping insulation. Upper curves: steel pipe; Lower curves: copper tube. 

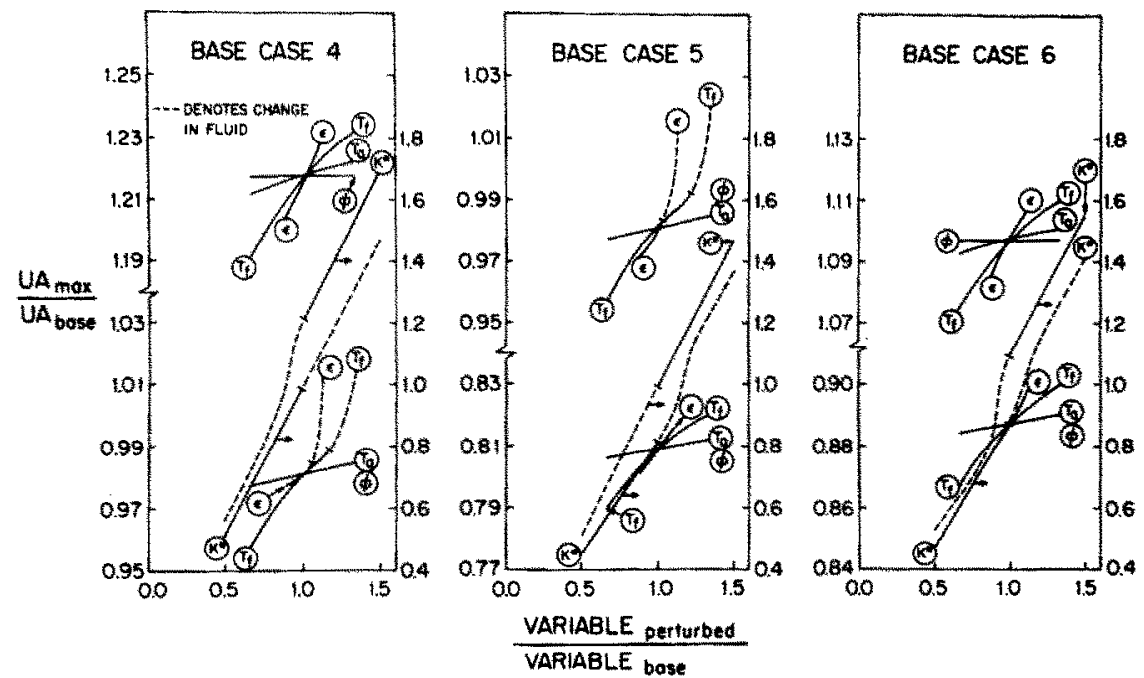

Fig. 4. Sensitivity analysis results for indoor piping insulation. Upper curves: steel pipe; Lower curves: copper tube.

The method of the sensitivity analysis was to describe six "base cases" defined in Table 2 and to evaluate the maximal deviations of perturbed $U A$ values from the $U A$ values for base-case conditions. The perturbation is conducted by varying one continuous variable at a time through its range of values for all 4 fluids, for all $D$ and $t_{i}$ combinations, and for $M_{p}$ equal to 1 and 2 , while leaving the rest of the base case continuous variables fixed at the values indicated in Table 2 . The above combinations resulted in computing more than 25000 values of $U A$.

The results of the sensitivity analysis are summarized in Figs. 3 and 4. In the interest of clarity, the values $U A_{\max } / U A_{\text {base }}$ were plotted only for that combination of $f_{L}, D$ and $t_{i}$ which yielded the maximal deviation in $U A$. Hence, these curves show the maximal possible influence of the investigated variables on $U A$.

\subsection{Indoor Hot Water Storage Tanks}

Here

$$
U A^{\prime}=U A^{\prime}\left(d_{2}, t_{i}, k_{p}, t_{p}, T_{f}, T_{a}, \epsilon, k_{i}\right) .
$$

The ranges of the variables $T_{f}, T_{a}, \epsilon$, and $k_{i}$ are the same as for pipes. Cylindrical steel tanks of outside diameter $d_{2}$, length $l$, and wall thickness $t_{p}=\frac{3}{16}$ are considered (applicability of results to other wall thicknesses is permitted since the effect of $t_{p}$ on the $U A$ value is small), where

$$
\begin{array}{r}
1.5 \leq d_{2} \leq 9 \mathrm{ft} \\
5 \leq l \leq 9 \mathrm{ft}
\end{array}
$$

and

$$
t_{i}: \frac{1}{2}, 1,2,3,4,5,6,7,8,10,12,14,16,18,20,22,24 \text { in. }
$$

The "base case" here is described in Table 3. The results of the analysis are shown in Fig. 5 ,

\subsection{Conclusions from the Sensitivity Analysis}

As expected in all cases, the major influence on $U A$ is through the insulation's thermal conductivity and thickness. The influence of all other variables is at least an order of magnitude smaller than that of $k^{*}$. Specifically, for outdoor piping cases, only wind velocity variations in its range influences the $U A$ value to any noticeable extent, this effect being only $\pm 3 \%$. For the outdoor piping cases, the hot fluid temperature $T_{f}$ and the insulation's emissivity $\epsilon$ show an effect of $\pm 3 \%$ each on $U A$. For the indoor 
Table 3. The base case for storage tank insulation sensitivity analysis.

\begin{tabular}{lccccc}
\hline \multicolumn{1}{c}{ Location } & $\begin{array}{l}\text { Base } \\
\text { case }\end{array}$ & $T_{f},{ }^{\circ} \mathbf{F}\left({ }^{\circ} \mathrm{C}\right)$ & $\begin{array}{c}\text { Value of base case variables } \\
T_{a},{ }^{\circ} \mathrm{F}\left({ }^{\circ} \mathrm{C}\right)\end{array}$ & $\epsilon$ & $k^{*}$ \\
\hline $\begin{array}{l}\text { Indoor } \\
\begin{array}{l}\text { Storage } \\
\text { Tanks }\end{array}\end{array}$ & 7 & $150(66)$ & & & \\
& & $60(16)$ & 0.50 & 2 \\
\hline
\end{tabular}

hot water storage tanks, the influence of $T_{f}$ and $\epsilon$ are $\pm 5 \%$ and $\pm 8 \%$ respectively. The radiative losses become more pronounced for indoor insulation because they are comparable to the natural convection losses, whereas outdoor external surface heat transfer coefficients are dominated by wind-driven forced convection.

The type of heated liquid has a very small influence $( \pm 2 \%)$. It is maximal for the silicone oil which yields smaller $U A$ values than the other fluids.

Errors in $U A$ values (for a fixed insulation thickness) of up to $20 \%$ can result if they are calculated for one nominal pipe size and applied to the same nominal size for a different pipe material due to differences between actual diameters for the two cases. Such errors may occur when using the ETI manual ${ }^{3}$, however, for the present method the errors are reduced by evaluating all $U A$ values based on pipe material 3 .

Assuming a maximum allowable $U A$ error of $\pm 14 \%( \pm 19 \%$ for storage tank insulation), the results of the sensitivity analysis for the base cases and ranges listed can be summarized by

$$
U A=U A\left(D, t_{i}, k^{*}, \text { indoor or outdoor }\right)
$$

and

$$
U A^{\prime}=U A^{\prime}\left(d_{2}, t_{i}, k^{*}\right)
$$

Referring to eqn (8), the effects on $C_{T M}$ due to the above errors in $U A^{*}$ can be quantified by writing

$$
C_{T M} / C_{R}=1+u\left(U A^{*} / C_{R}\right)
$$

where $u$ is an error coefficient with values of

$$
\begin{aligned}
& 0.86 \leq u \leq 1.14 \text { for piping } \\
& 0.81 \leq u \leq 1.19 \text { for storage tanks. }
\end{aligned}
$$

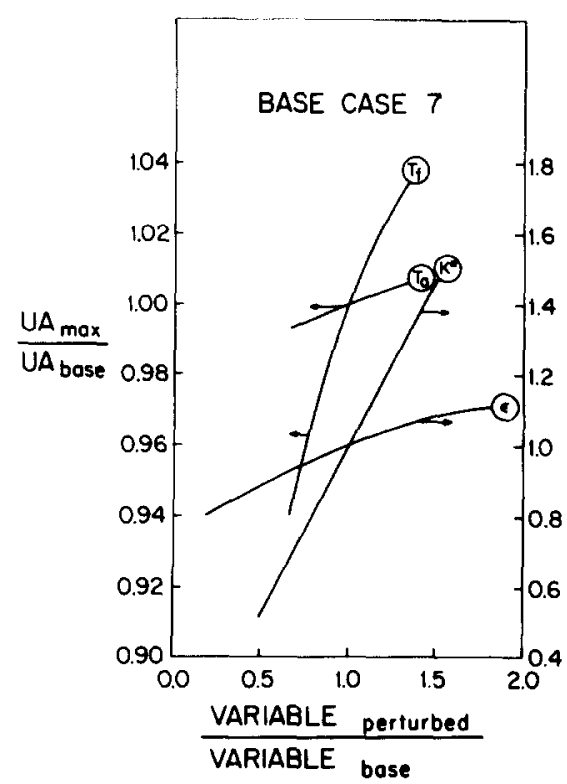

Fig. 5. Sensitivity analysis results for indoor hot water storage tank insulation. 
Using eqn (20), two limiting effects of $u$ on $C_{T M}$ are considered:

$$
\begin{aligned}
& C_{R} \ll U A^{*} \\
& C_{R} \gg U A^{*}
\end{aligned}
$$

For case (21), the second term on the right hand side of (20) becomes the dominant term on that side and $C_{T M}$ is then equal to $u\left(U A^{*}\right)$. For the case of (22), the first term on the right hand side of (20) is dominant and $C_{T M}$ is determined independently of $u$ or $U A^{*}$. Thus, the maximum error in $C_{T}$ due to an error in the $U A^{*}$ value is realized by case (21) and is the same as that error associated with the $U A^{*}$ value.

Table 4. Outdoor piping insulation number legend (for use with Fig. 6).

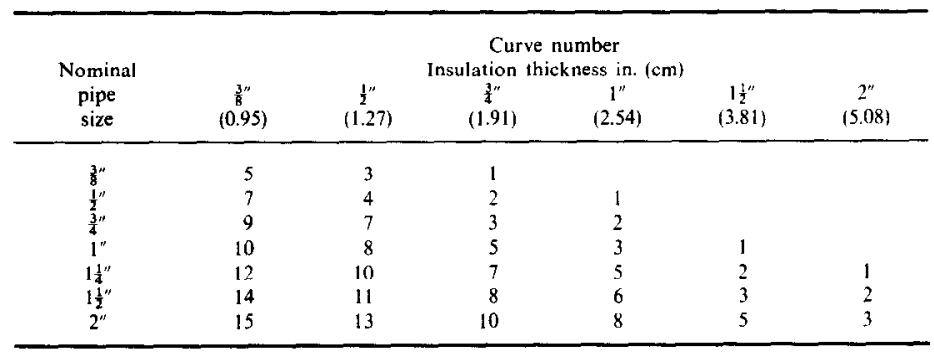

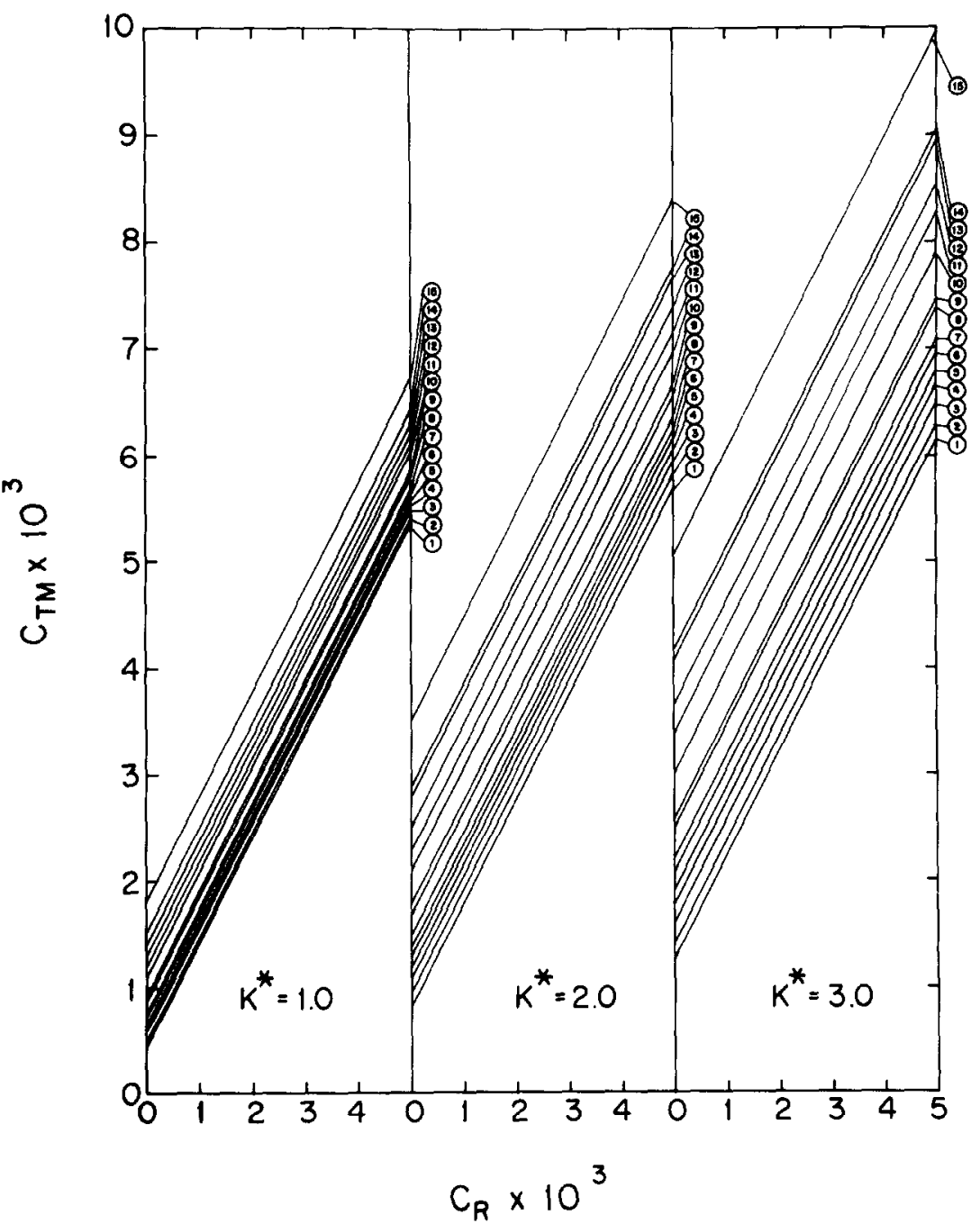

Fig. 6. Outdoor piping insulation design graphs (Base Case 3). Number legend is given in Table 4. $C_{R}$ is given in eqn $9 ; C_{T M}$ is the resultant total system cost. 


\section{DESIGN GRAPHS}

Equation (8) can be used to generate graphs relating system variables $C_{R}$ to system costs $C_{T M}$ by combining eqns (18), (19), and $U A$ variables defined from Base Case 3 for outdoor piping, Base Case 6 for indoor piping and Base Case 7 for indoor storage tanks. These become optimal insulation design graphs because $C_{R}$ can be varied to obtain minimal $C_{T M}$ from the graphs. Direct calculation of the optimal thickness through differentiation of the rate of heat loss with $t_{i}$ was not implemented for two reasons: (1) because the cost function is discontinuous due to the discrete values of commercial

Table 5. Indoor piping insulation number legend (for use with Fig. 7).

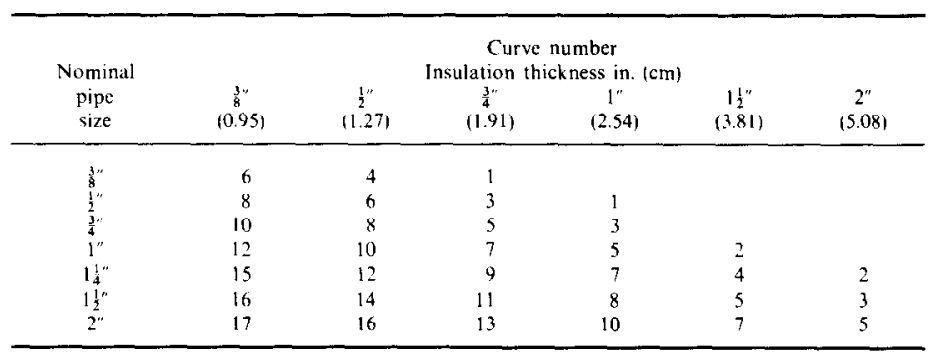

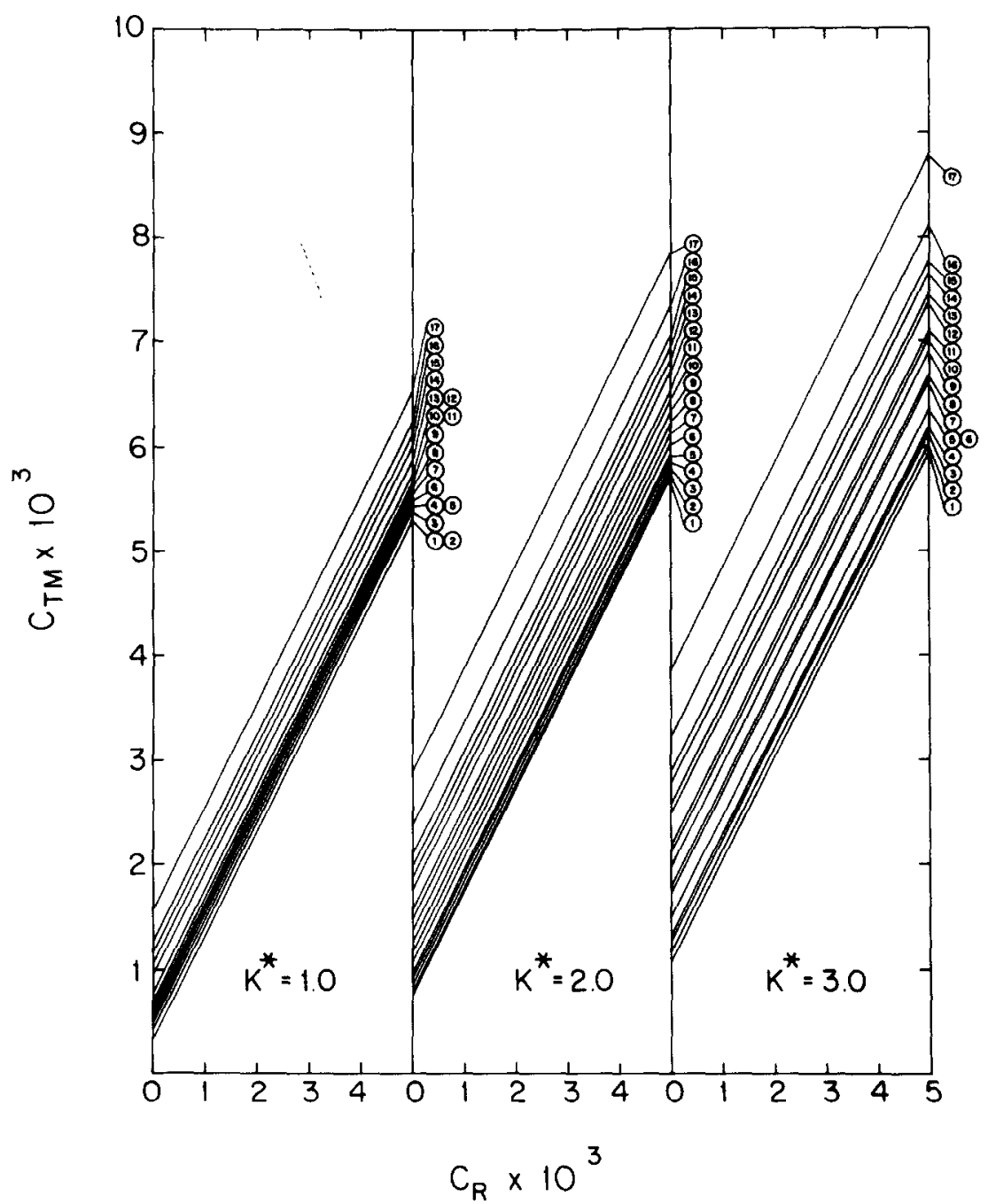

Fig. 7. Indoor piping insulation design graphs (Base Case 6). Number legend is given in Table 5. $C_{R}$ is given in eqn $9 ; C_{T M}$ is the resultant total system cost. 
pipe diameters and insulation thicknesses and (2) the present method provides more information by indicating $C_{T M}$ for a variety of $C_{R}$ values.

Equation (8) was thus plotted in Fig. 6 for outdoor piping insulation. Nomenclature for Fig. 6 is given in Table 4.

Table 6. Indoor hot water storage tank insulation number legend (for use with Fig. 8).

\begin{tabular}{|c|c|c|c|c|c|c|c|c|c|}
\hline \multirow{2}{*}{$\begin{array}{c}\text { Tank } \\
\text { outside } \\
\text { diameter. } \\
\text { feet }(m)\end{array}$} & \multicolumn{9}{|c|}{$\begin{array}{l}\text { Curve number } \\
\text { Insulation thickness inches }(\mathrm{cm})\end{array}$} \\
\hline & $(1.27)$ & $\begin{array}{c}1 \\
(2.54)\end{array}$ & $\begin{array}{c}2 \\
(5.08)\end{array}$ & $\begin{array}{c}3 \\
(7.62)\end{array}$ & $\begin{array}{c}4 \\
(10.16)\end{array}$ & $\begin{array}{c}5 \\
(12.7)\end{array}$ & $\begin{array}{c}6 \\
(15.24)\end{array}$ & $\begin{array}{c}7 \\
(17.78)\end{array}$ & $\begin{array}{c}8 \\
(20.32)\end{array}$ \\
\hline $\begin{array}{c}1 \frac{1}{2} \\
(0.45)\end{array}$ & 17 & 11 & 5 & 3 & 1 & & & & \\
\hline $\begin{array}{c}2 \\
(0.61)\end{array}$ & 20 & 14 & 8 & 5 & 3 & 2 & 1 & & \\
\hline $\begin{array}{c}3 \\
(0.91)\end{array}$ & 28 & 20 & 13 & 9 & 6 & 5 & 4 & 3 & 2 \\
\hline $\begin{array}{c}4 \\
(1.22)\end{array}$ & 32 & 25 & 16 & 12 & 9 & 7 & 6 & 5 & 4 \\
\hline $\begin{array}{c}5 \\
(1.52)\end{array}$ & 34 & 29 & 20 & 15 & 12 & 10 & 8 & 7 & 6 \\
\hline $\begin{array}{c}6 \\
(1.83)\end{array}$ & 36 & 31 & 23 & 18 & 15 & 12 & 10 & 9 & 8 \\
\hline $\begin{array}{c}7 \\
(2.13)\end{array}$ & & 33 & 27 & 21 & 18 & 14 & 13 & 11 & 10 \\
\hline $\begin{array}{c}8 \\
(2.44)\end{array}$ & & 35 & 29 & 24 & 20 & 17 & 15 & 13 & 12 \\
\hline $\begin{array}{c}9 \\
(2.74)\end{array}$ & & 36 & 30 & 26 & 22 & 19 & 16 & 15 & 13 \\
\hline
\end{tabular}

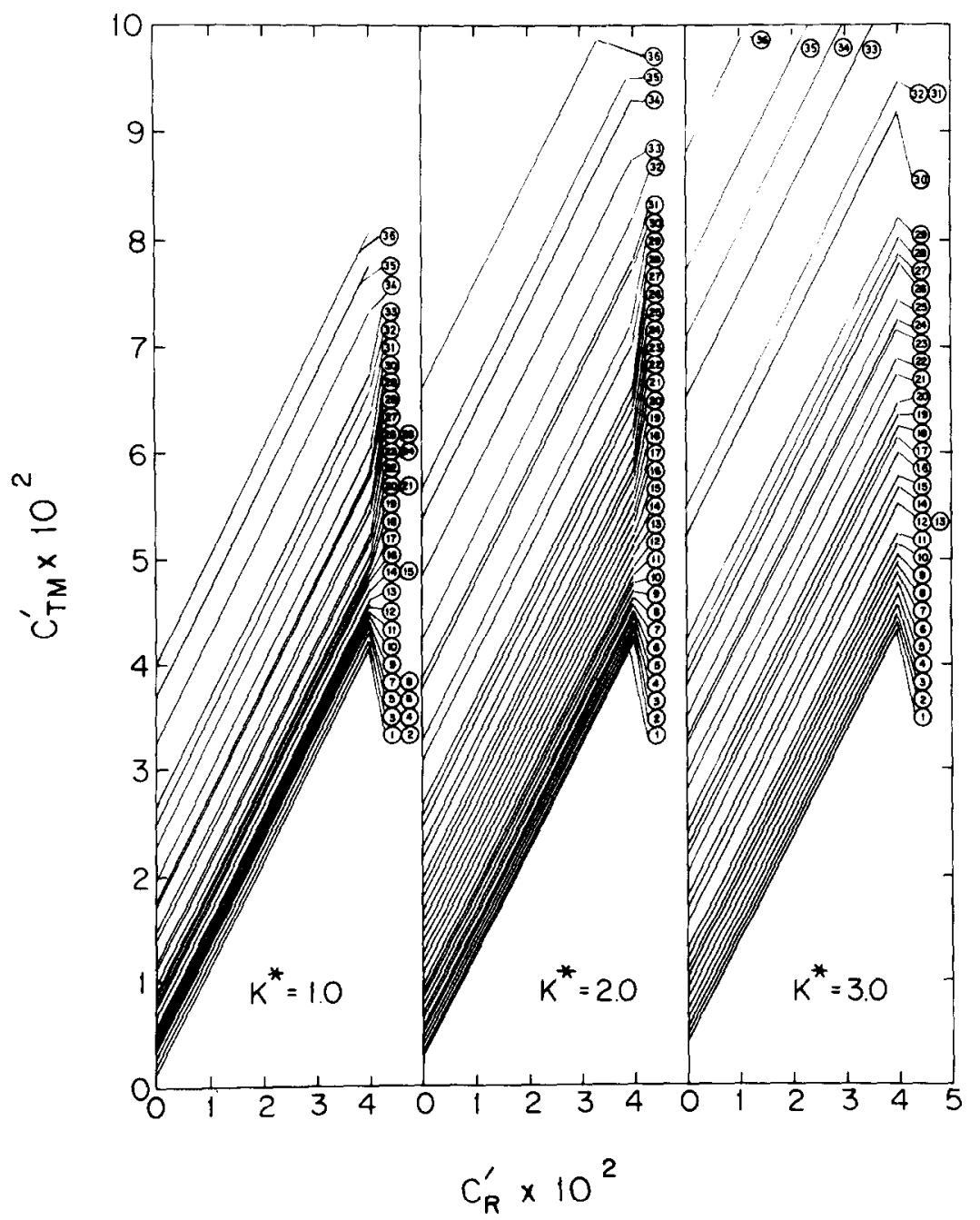

Fig. 8. Indoor hot water storage tank insulation design graphs (Base Case 7). Number legend is given in Table 6. $C_{R}^{\prime}$ is given by eqn 13, $C_{T M}^{\prime}$ is the resultant total system cost. 
Indoor piping insulation design graphs are shown in Fig. 7 with the $D$ and $t_{i}$ combination legend listed in Table 5. A comparison of like combinations of $D$ and $t_{i}$ from Figs. 6 and 7 indicate that $U A$ differences as large as $32 \%$ exist, justifying the development of both an indoor and outdoor piping insulation design graph. Indoor hot water storage tank insulation design graphs are shown in Fig. 8, with the $d_{2}$ and $t_{i}$ combination legend listed in Table 6 .

Inspection of Figs. 6, 7 and 8 with Tables 4, 5 and 6 shows that the "critical diameter" (the value of $d_{3}$ for which the $U A$ value is a maximum for all other independent variables fixed) is smaller than $d_{3}$ determined from any combination of pipe diameter and insulation thickness used in this analysis. Therefore, in all cases, $U A$ for a given pipe diameter decreases with increasing insulation thickness, thus confirming the statement made earlier that all diameters considered in this report are above critical. The optimal insulation thickness, total annual heat loss, insulation and heat loss costs and R-value are determined for a particular pipe (or tank) in a given system as follows:

(1) Obtain insulation material and jacketing costs for each insulation thickness starting from the smallest available thickness for the particular pipe size of interest, and from economic and system design information and labor costs which apply to the project, calculate $C_{R}$ (or $C_{R}^{\prime}$ ) for each thickness, using eqn (9) (or cqn (13)).

(2) Knowing whether the pipe to be insulated is indoor or outdoor, find from Table 4 or 5 (6) the curve numbers which correspond to the pipe (or tank) size and the insulation thicknesses.

(3) Knowing whether the pipe to be insulated is indoor or outdoor and the value of $k^{*}$ for the particular insulation under investigation, enter the $C_{R}$ (or $C_{R}^{\prime}$ ) value in the proper figure $(6,7$ or 8$)$.

(4) From the correct curve number read off the value of $C_{T M}$ (or $C_{T M}^{\prime}$ ) that corrresponds to each value of $C_{R}$ (or $C_{\mathrm{R}}^{\prime}$ ).

(5) The optimal insulation thickness is that which gives the smallest value of $C_{T M}$ (or $C_{T M}^{\prime}$ ). The $C_{T M}$ (or $C_{T M}^{\prime}$ ) axis intercept for this insulation thickness is the value $U A^{*}$ (or $U A^{* \prime}$ ).

For the optimal insulation thickness, the total annual cost per unit length of piping is

$$
C_{T}=C_{T M} C_{s} F\left(T_{f}-T_{a}\right), \$ / \text { yr.ft }
$$

and the total annual heat loss per unit length of insulated pipe is

$$
Q_{l}=\left(U A^{*}\right) F\left(T_{f}-T_{a}\right), 10^{6} \mathrm{Btu} / \mathrm{yr} . \mathrm{ft}
$$

For storage tanks, the total annual cost is:

$$
C_{T}^{\prime}=C_{T M}^{\prime} l C_{s} F\left(T_{f}-T_{a}\right), \$ / \mathrm{yr}
$$

and the total annual heat loss is:

$$
Q^{\prime}=\left(U A^{*}\right)^{\prime} l F\left(T_{f}-T_{a}\right), 10^{6} \mathrm{Btu} / \mathrm{yr} .
$$

In addition, the overall insulation $R$-value for a particular insulation thickness of cylindrical pipes and tanks $\uparrow$ is calculated by

$$
R\left(\text { or } R^{\prime}\right)=8760 \times 10^{-6} / U A^{*}\left(\text { or } U A^{* \prime}\right) \text {, ft length of cylinder. hr. }{ }^{\circ} \mathrm{F} / \mathrm{Btu}
$$

The procedure can be repeated for several differcnt insulation materials having different $k^{*}$ values to determine the economic optimal insulation material for a particular pipe (or tank) size. The system variables $F, C_{s}, T_{f}$ and $T_{a}$ can be determined by hourly computer simulation or by using annual averages by techniques such as proposed in Refs 4 and 5. $C_{S}$ can also be calculated from eqn (7). 


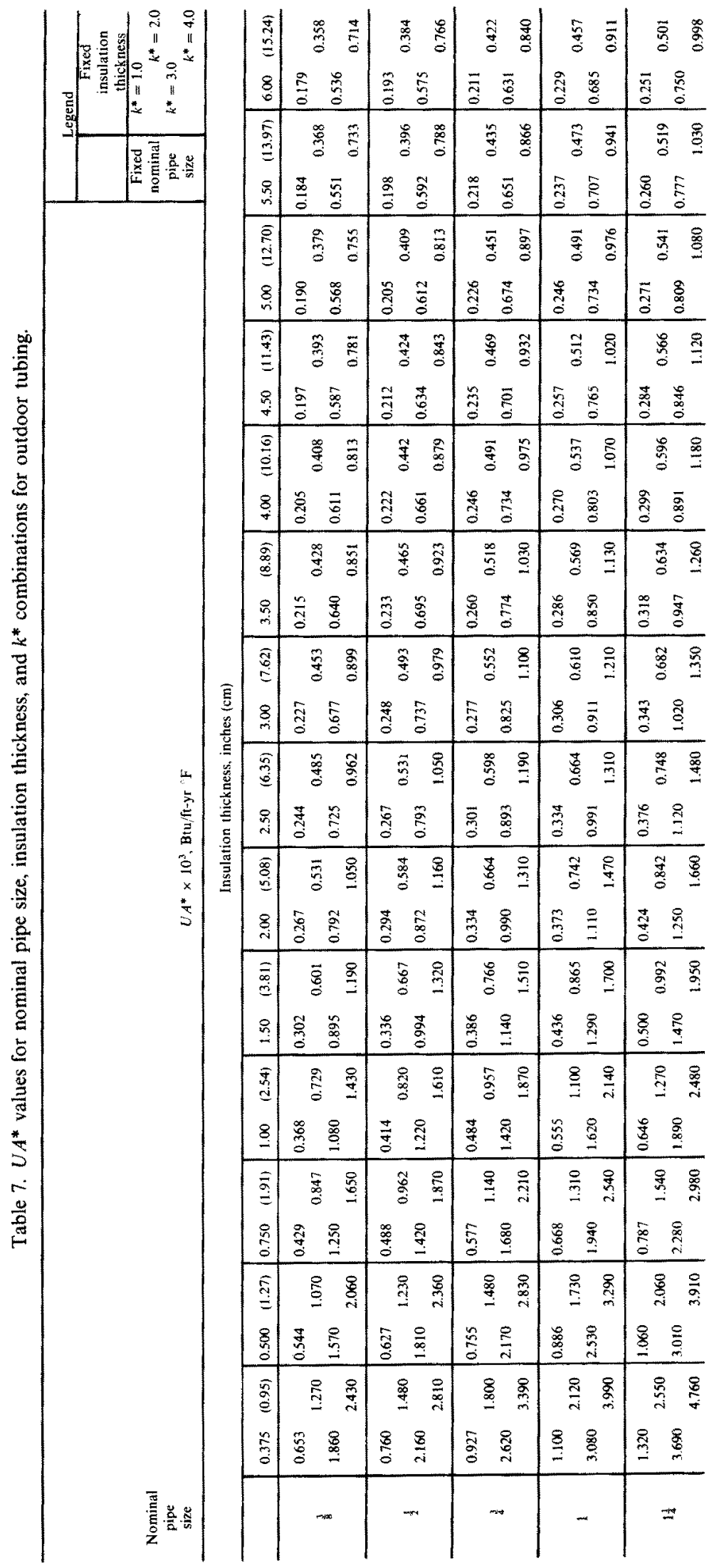




\begin{tabular}{|c|c|c|c|c|c|c|}
\hline $\begin{array}{l}\infty \\
0 \\
0 \\
0 \\
\end{array}$ & 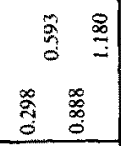 & 氕 & 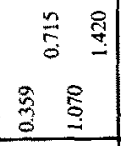 & 总总 & 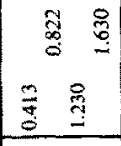 & 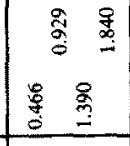 \\
\hline $0-7$ & 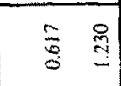 & $\therefore-7$ & $\frac{8}{2}$ & 8 & $5 ?$ & E \\
\hline 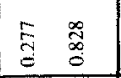 & $\begin{array}{l}0 \\
\end{array}$ & 装递 & $\frac{n}{3}$ & 憘蛋 & $\frac{2}{3}$ & $+\frac{8}{3}$ \\
\hline$E 8$ & 迸要 & $\pm \quad 9$ & $\notin 8$ & 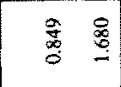 & 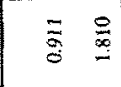 & 8 \\
\hline 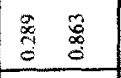 & $\begin{array}{ll}3 & 0 \\
3 & 0 \\
\end{array}$ & 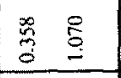 & \begin{tabular}{|ll} 
& 8 \\
3 & 0 \\
\end{tabular} & 染 & $\begin{array}{ll}5 \\
0 \\
0\end{array}$ & $\begin{array}{ll}2 \\
2 \\
3\end{array}$ \\
\hline 8 & 8 & $\begin{array}{ll}+0 \\
0\end{array}$ & 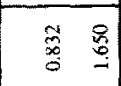 & $\overrightarrow{8}$ & : & 8 \\
\hline 表 & 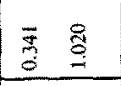 & 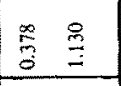 & 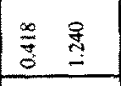 & $\frac{2}{3}$ & \begin{tabular}{|l} 
\\
\end{tabular} & 总商 \\
\hline $\begin{array}{ll}0 & 0 \\
0 & 0 \\
0 & 0 \\
0 & 4\end{array}$ & \& & 总总 & 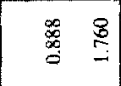 & 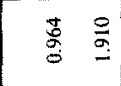 & 윰 & 8 \\
\hline $\bar{z}$ & 总 & 鉒要 & 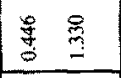 & 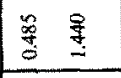 & 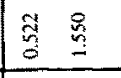 & 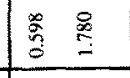 \\
\hline 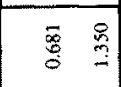 & $\bar{E}: 0$ & $\stackrel{8}{\underline{T}}$ & 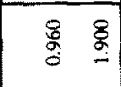 & 䙴 & 兽 & 85 \\
\hline : & 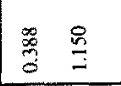 & $\begin{array}{l}3 \\
\end{array}$ & 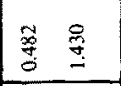 & 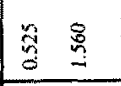 & 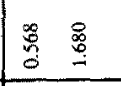 & 善善 \\
\hline 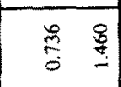 & 总 & 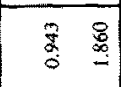 & $\stackrel{8}{8}$ & $\stackrel{8}{8}$ & $\frac{8}{8}$ & 里事 \\
\hline 8 & $\underset{8}{g}$ & 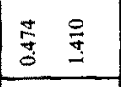 & 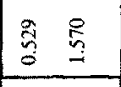 & 高 & 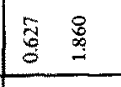 & 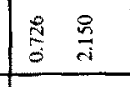 \\
\hline 8 & 总 & & 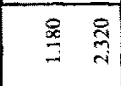 & & $\overline{8}$ & \\
\hline$\stackrel{\Xi}{3}$ & 墨总总 & 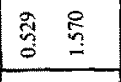 & 嘉总 & $\begin{array}{l}0 \\
0 \\
0\end{array}$ & $\begin{array}{ll} \\
5 \\
\end{array}$ & 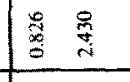 \\
\hline 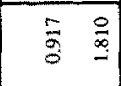 & 要 & 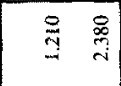 & 㐘 & 总 & 串 & $\stackrel{2}{2}$ \\
\hline $\begin{array}{l}0 \\
0\end{array}$ & 菺 & \begin{tabular}{|cc} 
\\
\end{tabular} & 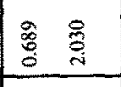 & $\begin{array}{ll} \\
0 \\
0\end{array}$ & 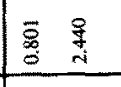 & 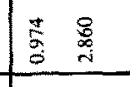 \\
\hline 8 & 品总 & & : & 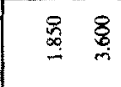 & 㒸总 & 8 \\
\hline$\stackrel{8}{\circ}$ & 䈶总 & 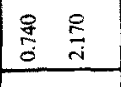 & 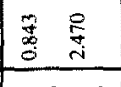 & \begin{tabular}{|cc}
0 \\
0 \\
0
\end{tabular} & 鄫 & 承 \\
\hline 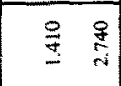 & 总 & 苾 & 承 & 品爱 & 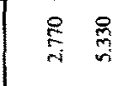 & $\stackrel{\circ}{p}$ \\
\hline$\stackrel{8}{\circ}$ & 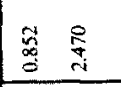 & 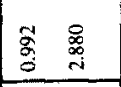 & 里高 & \begin{tabular}{|cc} 
\\
$:$
\end{tabular} & 事: & 总高 \\
\hline$\stackrel{8}{9}$ & 善善 & 委 & 悉 & 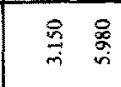 & $\frac{8}{80}$ & $\frac{2}{8}$ \\
\hline 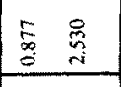 & 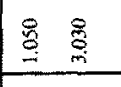 & 喅总 & $\frac{8}{9}$ & 急 & $\frac{8}{8}$ & $\frac{8}{\frac{8}{1}} \frac{8}{0}$ \\
\hline $\begin{array}{ll}0 \\
3 & 2 \\
7\end{array}$ & 爵 & \& & 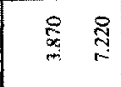 & $\frac{9}{7} \underset{7}{9}$ & 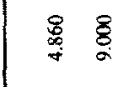 & 嗂 \\
\hline 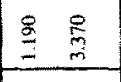 & 量孚 & 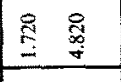 & 总 & 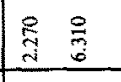 & 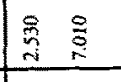 & 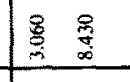 \\
\hline$\underset{\infty}{\infty}$ & 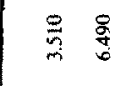 & $\frac{8}{g}$ & $\underset{\sim}{\infty}$ & 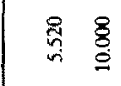 & 急 & 患 \\
\hline$\frac{8}{7}$ & 总 & $\frac{0}{0} 8$ & 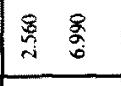 & \begin{tabular}{|cc}
8 \\
\end{tabular} & \begin{tabular}{|cc}
8 & 8 \\
3 & 0 \\
\end{tabular} & $\frac{8}{2}$ \\
\hline & & & m & & & \\
\hline
\end{tabular}




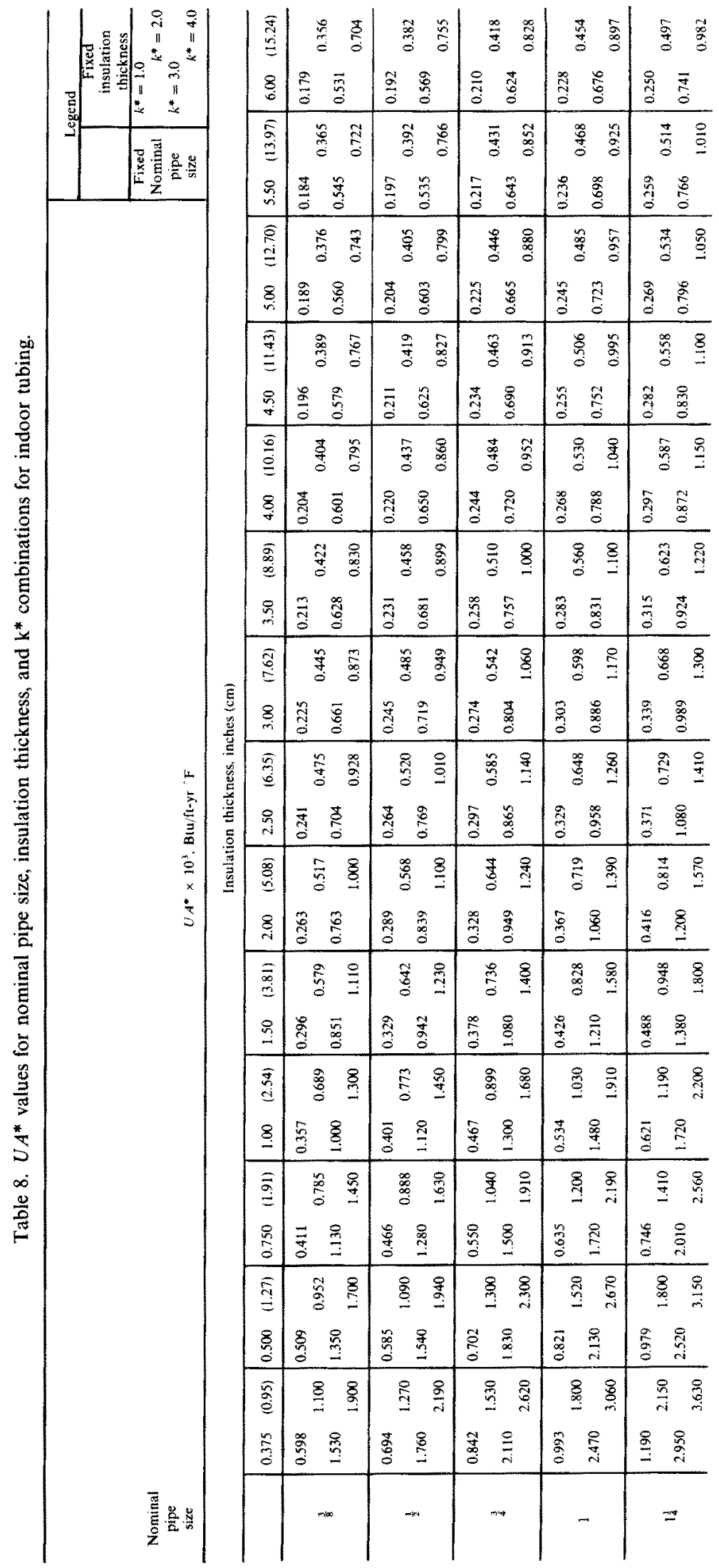




\begin{tabular}{|c|c|c|c|c|c|c|}
\hline 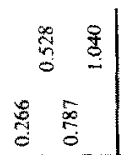 & 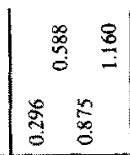 & 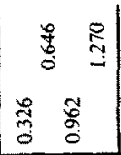 & 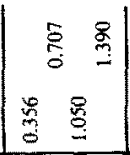 & 美总 & 윰 & \begin{tabular}{|l|l} 
\\
\\
\end{tabular} \\
\hline 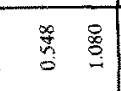 & $\overrightarrow{0}$ & है & 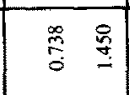 & $\begin{array}{ll}0 \\
: 0\end{array}$ & $\begin{array}{|cc|}0 & 0 \\
0 & 0 \\
0 & 0 \\
\end{array}$ & \\
\hline$\stackrel{\circ}{\frac{\circ}{0}}$ & 器喜 & 盖 & $\frac{8}{3}$ & 箩 & 胥 & 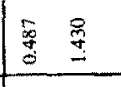 \\
\hline 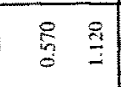 & 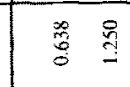 & $\begin{array}{ll}0 \\
0\end{array}$ & 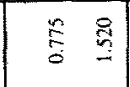 & 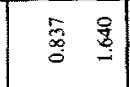 & 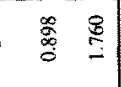 & \\
\hline 恶 & च & 象葛 & $\frac{0}{3}$ & $\frac{3}{8}$ & 藏兽 & $\frac{6}{2}$ \\
\hline $\begin{array}{ll}5 & 2 \\
= & \end{array}$ & 总 & 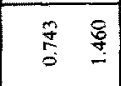 & 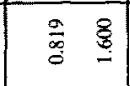 & 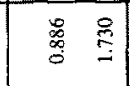 & 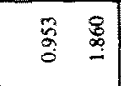 & \\
\hline 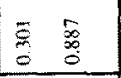 & 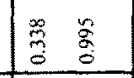 & $\begin{array}{ll}0 \\
\end{array}$ & $\frac{1}{5}$ & 琶盖总 & 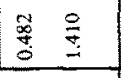 & 50 \\
\hline 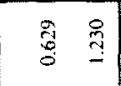 & 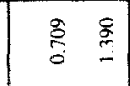 & 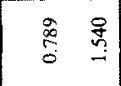 & \begin{tabular}{cc}
0 & 8 \\
\hdashline & 0
\end{tabular} & 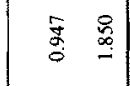 & 旁: & $\stackrel{R}{\Xi}$ \\
\hline 喜 & \begin{tabular}{ll}
$\infty$ \\
\hdashline \\
$e$
\end{tabular} & $\frac{D}{9}$ & 琶盖 & 噌是 & 5 & 㞔 \\
\hline 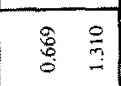 & 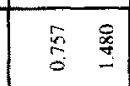 & 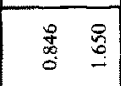 & 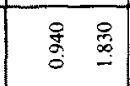 & $8 \%$ & $\begin{array}{ll}8 & 0 \\
& 0 \\
\end{array}$ & : \\
\hline g & 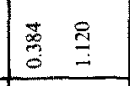 & 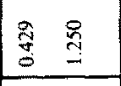 & 器 & 产 & 要 & 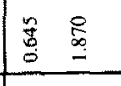 \\
\hline \begin{tabular}{|c|c|}
8 \\
8
\end{tabular} & $\begin{array}{l}\mathscr{8} \\
\mathscr{\delta}\end{array}$ & 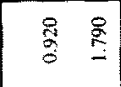 & $\frac{8}{9}$ & 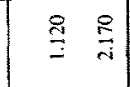 & $\stackrel{0}{\circ}$ & \\
\hline 8 & 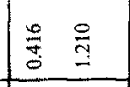 & 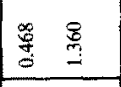 & $\frac{1}{2}$ & 居总 & 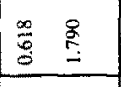 & 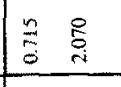 \\
\hline $\begin{array}{ll}0 \\
0\end{array}$ & 产 & 2 & 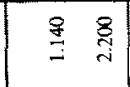 & 总 & \begin{tabular}{ll}
8 & 8 \\
\hdashline & 0
\end{tabular} & 㩊 \\
\hline 8 & 暻总 & 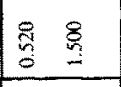 & 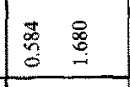 & 喜亭 & $\begin{array}{ll}5 \\
8 \\
8\end{array}$ & 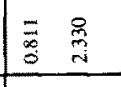 \\
\hline $\begin{array}{ll} & 8 \\
0 & 8 \\
0 & 8 \\
0 & -1\end{array}$ & 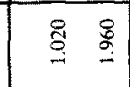 & $\stackrel{8}{8}$ & \begin{tabular}{ll}
0 \\
\hdashline \\
\hdashline
\end{tabular} & 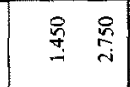 & 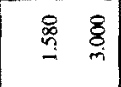 & 0 \\
\hline 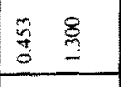 & 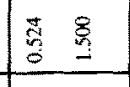 & 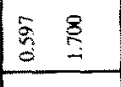 & 蒙 & $\frac{7}{7}$ & 染 & \begin{tabular}{|cc} 
& 8 \\
3 & 5 \\
0 & 5 \\
\end{tabular} \\
\hline $\begin{array}{ll}3 \\
3\end{array}$ & O‡ & 蛋 & 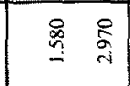 & $\begin{array}{ll}8 \\
8\end{array}$ & 80 & 곡 \\
\hline 8 & $\begin{array}{r}8 \\
8 \\
8\end{array}$ & 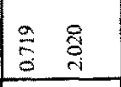 & 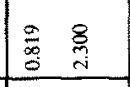 & 首 & 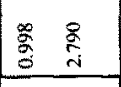 & 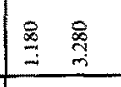 \\
\hline 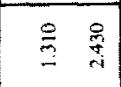 & $\begin{array}{cc}8 \\
8 \\
0\end{array}$ & $\begin{array}{ll}\circ & 8 \\
& 0 \\
\end{array}$ & 䕤 & 屜 & 量 & 8 \\
\hline 8 & 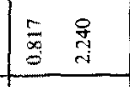 & $\begin{array}{l}0 \\
0 \\
0\end{array}$ & 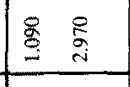 & 형 & 8 & $\frac{8}{8}$ \\
\hline 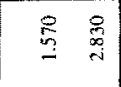 & 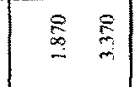 & 悉患 & 总鸹 & 蛋 & $\frac{0}{8}$ & $\stackrel{\circ}{\circ}$ \\
\hline 范 & 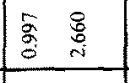 & $\equiv 8$ & 总总 & 黾 & $8 \begin{array}{l}8 \\
9\end{array}$ & 急急 \\
\hline 害号 & 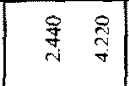 & 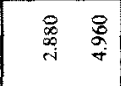 & \begin{tabular}{ll}
8 & 8 \\
\hdashline & 8 \\
\hdashline
\end{tabular} & 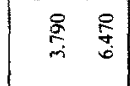 & $\frac{8}{7} \stackrel{8}{\circ}$ & 善 \\
\hline $8 \stackrel{8}{8}$ & 总总 & 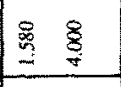 & 蛋蛋 & 愛 & 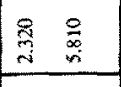 & 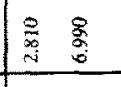 \\
\hline 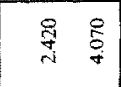 & 票总 & 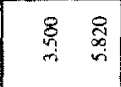 & 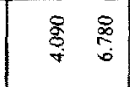 & 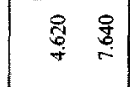 & 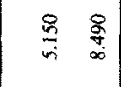 & 웜 \\
\hline$\frac{0}{3}$ & 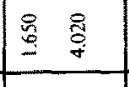 & 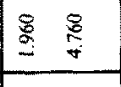 & 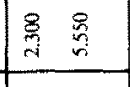 & 产 : & 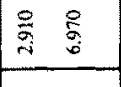 & 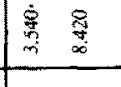 \\
\hline & & & & & & \\
\hline
\end{tabular}




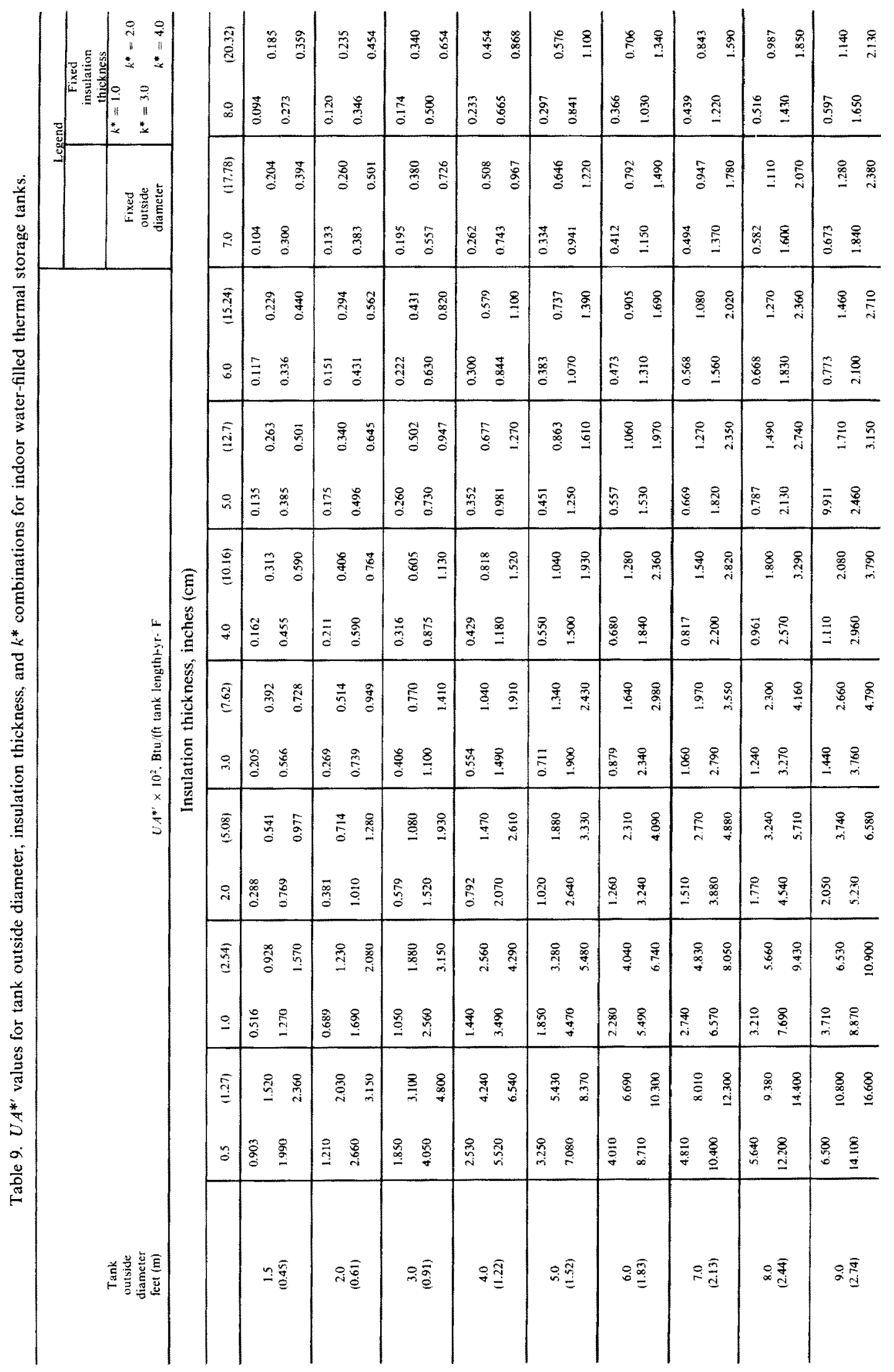




\begin{tabular}{|c|c|c|c|c|c|c|c|c|c|}
\hline 8 & $\frac{8}{8}$ & $\frac{8}{0} \quad \stackrel{n}{i j}$ & $\begin{array}{ll} & 8 \\
0 & 0 \\
0\end{array}$ & $\stackrel{\infty}{\stackrel{\infty}{0}} \stackrel{8}{3}$ & 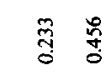 & 总 导 & 品 蒙 & 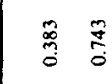 & 尔 \\
\hline \pm & $\frac{\tilde{c}}{0} \frac{\check{c}}{0}$ & 管 & 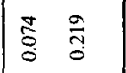 & 旾 & $\stackrel{\infty}{=} \frac{\text { o }}{0}$ & $\mid \begin{array}{ll}\frac{f}{0} & \frac{n}{f} \\
0 & 0\end{array}$ & $\begin{array}{ll}\infty \\
\frac{\infty}{0} \\
0\end{array}$ & $\frac{\sigma}{0}$ & đृ \\
\hline 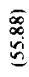 & $\frac{\infty}{0} \frac{\infty}{0}$ & $\stackrel{n}{\bar{z}}$ & $\begin{array}{cc}0 \\
\stackrel{0}{0} \\
0\end{array}$ & 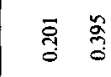 & 急 孪 & $\begin{array}{l}\text { 鹤 } \\
0\end{array}$ & 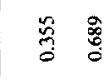 & $\stackrel{m}{\bar{F}} \stackrel{\infty}{\circ}$ & 管 \\
\hline N & 串 & $\stackrel{\infty}{0} \stackrel{E}{0}$ & 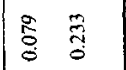 & 总 & 苛 & $\frac{\pi}{0} \frac{Z}{0}$ & $\frac{\bar{\alpha}}{0} \stackrel{\mathbb{\sigma}}{0}$ & 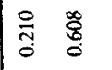 & 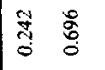 \\
\hline 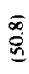 & $\frac{8}{0} \frac{\infty}{0}$ & $\underset{\mathbb{I}}{\stackrel{\Xi}{d}}$ & $\begin{array}{cc}\stackrel{0}{0} & 0 \\
0 & 0 \\
0\end{array}$ & 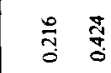 & 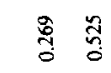 & $\stackrel{\vec{a}}{\overrightarrow{0}} \overline{0}$ & 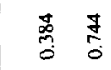 & $\underset{\substack{f \\
0}}{\substack{0 \\
0}}$ & $\begin{array}{ll}\frac{t}{n} \\
0 \\
0\end{array}$ \\
\hline ㄱ & $\overline{\bar{g}} \frac{\bar{n}}{\bar{\delta}}$ & $\underset{\delta}{\stackrel{a}{0}}$ & 然 & $\frac{8}{0} \overline{0}$ & $\frac{0}{0}$ & 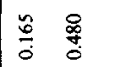 & $\stackrel{5}{\circ}$ & 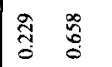 & 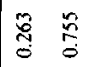 \\
\hline$q$ & $\stackrel{\bar{b}}{\overrightarrow{3}}$ & $\begin{array}{cc}\vec{g} & \infty \\
0 & 0 \\
0\end{array}$ & 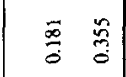 & 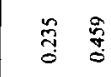 & సิ ڤ̊ & 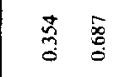 & 承 $\overline{\bar{x}}$ & 粍 & 莣 \\
\hline 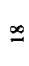 & 蒫 $\frac{8}{0}$ & $\frac{2}{2}$ & 可 & 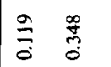 & $\frac{\substack{0 \\
0}}{0}$ & $\frac{\infty}{0} \tilde{0}$ & 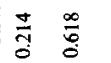 & $\begin{array}{ll}\bar{\sigma} & \vec{t} \\
0\end{array}$ & 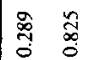 \\
\hline 高 & $\cong$ & $\underset{0}{\sharp}$ & $\begin{array}{cc}5 & 0 \\
\vdots \\
0\end{array}$ & 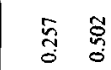 & $\approx \tilde{\tilde{\sigma}}$ & 离 & 索 & 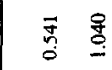 & $\stackrel{8}{8}$ \\
\hline 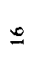 & 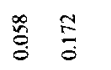 & $\tilde{D}=$ & $\frac{8}{0}$ बे & $\overrightarrow{\vec{\theta}} \overline{0}$ & $\begin{array}{ll}70 \\
0 \\
0\end{array}$ & $\mid \begin{array}{cc}0 & 0 \\
0 & 5 \\
0 & 5 \\
0\end{array}$ & 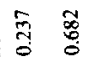 & 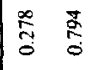 & $\overline{\bar{\sigma}} \overline{\bar{\sigma}}$ \\
\hline 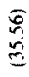 & 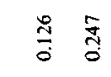 & $\frac{n}{0}$ & $\stackrel{g}{\tilde{z}} \bar{g}$ & 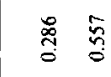 & 商 & 勇 范 & 总 & : & 总 \\
\hline \pm & $\frac{\infty}{0}$ & 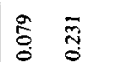 & 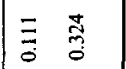 & $\frac{7}{0}$ & $\frac{\infty}{0}$ 号 & $\begin{array}{ll}\text { त्व } & \tilde{d} \\
\text { du }\end{array}$ & 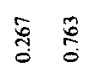 & 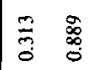 & $\overline{0}$ \\
\hline 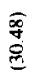 & 总 & 超 & 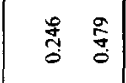 & 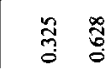 & 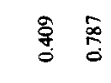 & 商 & 要 & 행 & 总 \\
\hline$\simeq$ & है & $\begin{array}{ll}\infty & \tilde{y} \\
0 \\
0\end{array}$ & 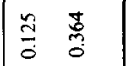 & $\frac{8}{8}$ & 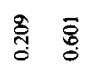 & 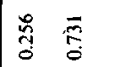 & $\begin{array}{ll}: & \infty \\
0 \\
0 \\
0 \\
0\end{array}$ & 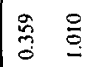 & $\frac{8}{f}$ \\
\hline 0 & $\stackrel{\infty}{\stackrel{\infty}{0}} \stackrel{\substack{0 \\
0}}{0}$ & $\begin{array}{l}\infty \\
\stackrel{\infty}{0} \\
0\end{array}$ & 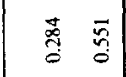 & 홍 & 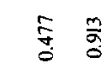 & 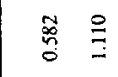 & 余 & 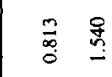 & 商 \\
\hline$\cong$ & 麊 & 吾 & 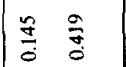 & $\frac{a}{9}$ & 瓷 & 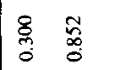 & $\stackrel{\infty}{\frac{\infty}{2}}$ & $\underset{\tilde{z}}{\tilde{z}} \stackrel{\circ}{=}$ & 尊 \\
\hline & $\stackrel{9}{=}$ & 울 & $\stackrel{\overline{\hat{a}}}{\dot{\rho}}$ & & 옴 & $\stackrel{\stackrel{\tilde{\infty}}{=}}{=}$ & $\therefore \frac{\bar{z}}{\mathrm{~d}}$ & $\stackrel{8}{\mathbb{J}}$ & $\therefore \frac{F}{d}$ \\
\hline
\end{tabular}




\section{DESIGN TABLES}

Should more precision be desired in the optimal insulation selection, a method is presented which provides the actual numerical $U A^{*}$ values listed in Tables 7,8 and 9 for outdoor (Base Case 3) and indoor (Base Case 6) piping and indoor storage tanks (Base Case 7), respectively. The optimal insulation thickness and associated information is determined for a particular pipe (or tank) in a given system as follows:

(1) Repeat step (1) of the previous section.

(2) From the applicable Table 7, 8 or 9, find the value of $U A^{*}$ (or $U A^{*^{\prime}}$ ) which corresponds to the particular pipe (or tank) size under consideration for the proper value of $k^{*}$ and for the range of insulation thicknesses being investigated.

(3) Obtain $C_{T M}$ (or $C_{T M}^{\prime}$ ) by adding the values of $U A^{*}$ (or $U A^{* \prime}$ ) and $C_{R}$ (or $C_{R}^{\prime \prime}$ ) which correspond to the same pipe size and insulation thickness combination.

(4) The optimal insulation thickness is that which gives the smallest value of $C_{T M}$ (or $C_{T M}^{\prime}$ ). The optimum value of $U A^{*}$ (or $U A^{*^{\prime}}$ ) is that which corresponds to the optimal insulation thickness. Equations to determine the annual heat loss, associated material and heat loss costs, and R-values are the same as those given in Section 4. The above procedure can be repeated for several different insulation materials having different $k^{*}$ values to determine the economic optimal insulation material for a particular pipe (or tank) size.

\section{INSULATION DESIGN EXAMPLE: THE UNIVERSITY OF PENNSYLVANIA SOLAROW HOUSE}

\subsection{Description of System and Design Data}

The University of Pennsylvania SolaRow house is a three storey brick row house located just south of the campus in Philadelphia. It was retro-fitted for both solar space and water heating (cf. Lior et al. ${ }^{6}$ ). Water is circulated from three 350 gallon storage tanks $\dagger$ located in the basement to 33 flat-plate solar collectors located on the roof. Net collection area is $475 \mathrm{ft}^{2}$. The collectors are arranged in five rows. Each row has either five or seven collectors connected in parallel and the rows are connected in series. The main collector supply and return lines consist of $1 \frac{1}{2}$ type $\mathrm{L}$ nominal copper water tube. The collector upper and lower distribution headers are $2^{\prime \prime}$ nominal tube size. These nearly horizontal pipes are larger to minimize frictional resistance during gravity-driven draindown. Upon demand for house heating, the solar heated water is circulated automatically from the tanks through $1^{\prime \prime}$ nominal copper tubes to and from a water-to-air heat exchanger located at the air intake of a fuel fired auxiliary furnace. Existing ducts then distribute the air throughout the house. In addition, a domestic hot water preheat heat exchanger is immersed in two of the three storage tanks to supply preheated city water to the existing gas-fired domestic hot water heater. Freeze protection is by automatic drain-down into the thermal storage tanks when the water temperature drops below $38^{\circ} \mathrm{F}$. To minimize admission of oxygen and startup transients, the water is retained in the pipes at higher temperatures, even when no water circulation is taking place.

To determine the optimal insulation, the following data (see Section 2.2) are applied for the University of Pennsylvania SolaRow house:

$$
\begin{aligned}
M_{i} & =\$ 20,000 \\
M_{0}+M_{m} & =\$ 50.00 \\
L_{B} & =165 \times 10^{6} \mathrm{Btu} \\
\eta & =0.47 \\
n_{(1)}=n_{(2)} & =25 \mathrm{yr} \\
\theta & =0 \\
\alpha_{(1)}=\alpha_{(2)} & =0.2 \\
\beta_{(1)}=\beta_{(2)} & =0
\end{aligned}
$$

$$
\begin{aligned}
p & =0.005 \\
h_{(1)}=h_{(2)} & =0.003 \\
m_{(1)}=m_{(2)} & =20 \mathrm{yr} \\
i_{(1)}=i_{(2)} & =0.09 \\
r_{m(1)}=r_{m(2)}=r_{0(1)}=r_{0(2)} & =0.06 \\
B & =0 \\
T_{f} \text { outdoor } & =110^{\circ} \mathrm{F} \\
T_{f} \text { indoor } & =90^{\circ} \mathrm{F}
\end{aligned}
$$

†Diameter $=3^{\prime}$, height $=7^{\prime}$. 


$$
\begin{aligned}
\sigma_{(1)}=\sigma_{(2)} & =0 \\
g & =0.06 \\
d & =0.07 \\
t & =0.18 \\
t_{1} & =0
\end{aligned}
$$

$$
\begin{aligned}
\text { For all outdoor piping } & =F\left(T_{f}-T_{a}\right)=24^{\circ} \mathrm{F} \\
\text { For indoor piping } & =F\left(T_{f}-T_{a}\right)=23^{\circ} \mathrm{F} \\
\text { For thermal storage tanks } & =F\left(T_{f}-T_{a}\right)=63^{\circ} \mathrm{F} \\
C_{m} & =0.03 \$ / \mathrm{ft}
\end{aligned}
$$

$T_{f}, F\left(T_{f}-T_{a}\right)$, and $\eta$ were determined from estimates supplied by SOLSYS, the University of Pennsylvania solar heating system simulation computer program ${ }^{7}$ which used Philadelphia hourly ambient temperatures and insolation values.

\subsection{Optimization Example}

Using the above information and the E-values calculated in Appendix B, the cost of solar heat is obtained from eqn (7) as

$$
C_{s}=\{[20000(1.173)+50(20.9226)] /(0.47) 165(25)\}+0=\$ 12.64 / 10^{6} \mathrm{Btu} .
$$

It is important to note that $\eta=0.47$ (as assumed here) only when there are no heat losses through insulation. Hence, after the optimal insulation values are determined, these heat losses must be calculated, and the value of $\eta$ modified. Since $\eta$ would decrease, $C_{s}$ would increase, and several iterations of the procedure may need to be performed. As described in more detail in Section 6.3 below, only two iterations were needed in all cases considered here. Continuing the first iteration, $C_{R}$ can be computed for outdoor piping from eqn (9) as:

$$
\begin{aligned}
C_{R}=\left[1.173\left(C_{i}+C_{j}+C_{l}\right)+(20.9226) 0.03\right] / 25(12.64)(24) \\
=(1.1547) 10^{-4}\left(C_{i}+C_{j}+C_{l}\right)+(8.236) 10^{-5}
\end{aligned}
$$

Based on specific values of $\left(C_{i}+C_{j}+C_{l}\right)$, eqn (28) is used to determine the optimal fiberglass insulation $\left(k^{*}=2.0\right)$ thickness for an outdoor-located $1 \frac{1}{2}$ " copper tube used in SolaRow, as demonstrated in Table 10, By inspection of the last column (first iteration), the minimal value of $C_{T M}$ is $1.628 \times 10^{-3}$. Therefore, the optimal insulation thickness is $1 \frac{1}{2}$ with a total annual heat loss per unit length (from (24)) of

$$
Q_{l}=(1.09) 10^{-3}(24)=0.0262 \times 10^{6} \mathrm{Btu} / \mathrm{ft}-\mathrm{yr} \text {. }
$$

The total present value average annual cost of insulation per unit length (from (23)) is:

$$
C_{T}=(1.628) 10^{-3}(12.64) 24=\$ 0.49 / \mathrm{ft}-\mathrm{yr} .
$$

It is interesting to note that of the total present value average annual cost per foot, $\$ 0.33$ or $67 \%$ is for energy $\left(C_{T M}=U A^{*}\right.$ for $\left.C_{R}=0\right)$ and the remainder is for insulation material and labor. As shown in Section 6.3 below, the heat losses through the total system's insulation were not negligible. As mentioned above, $\eta$ must be recalculated. The second iteration changed the optimal insulation thickness to 2 " and correspondingly changed the above values of $Q_{l}$ and $C_{T}$. The second iteration is also shown in Table 10.

\subsection{Results and Comparison with the ETI Method}

By following the procedure used in the construction of Table 10, the optimal insulation was determined for all tubing sizes and storage tanks in the SolaRow house solar heating system. Table 11 lists the major results obtained by both the present technique and the ETI method ${ }^{3}$.

Table 11 also shows the percentage of the computed useful solar energy collected which is lost through the optimal insulation thickness ( $24.9 \%$ total for the first iteration) and through the actual insulation thickness (32.3\% total) installed in SolaRow. Although the heat escaping through insulated surfaces in the basement does not represent a complete loss in winter, the total losses through insulation are significant. They could be reduced if the length of pipe and surface areas of thermal storage tanks can be reduced, and if the residence time of the warm working fluid (water in this case) can be 


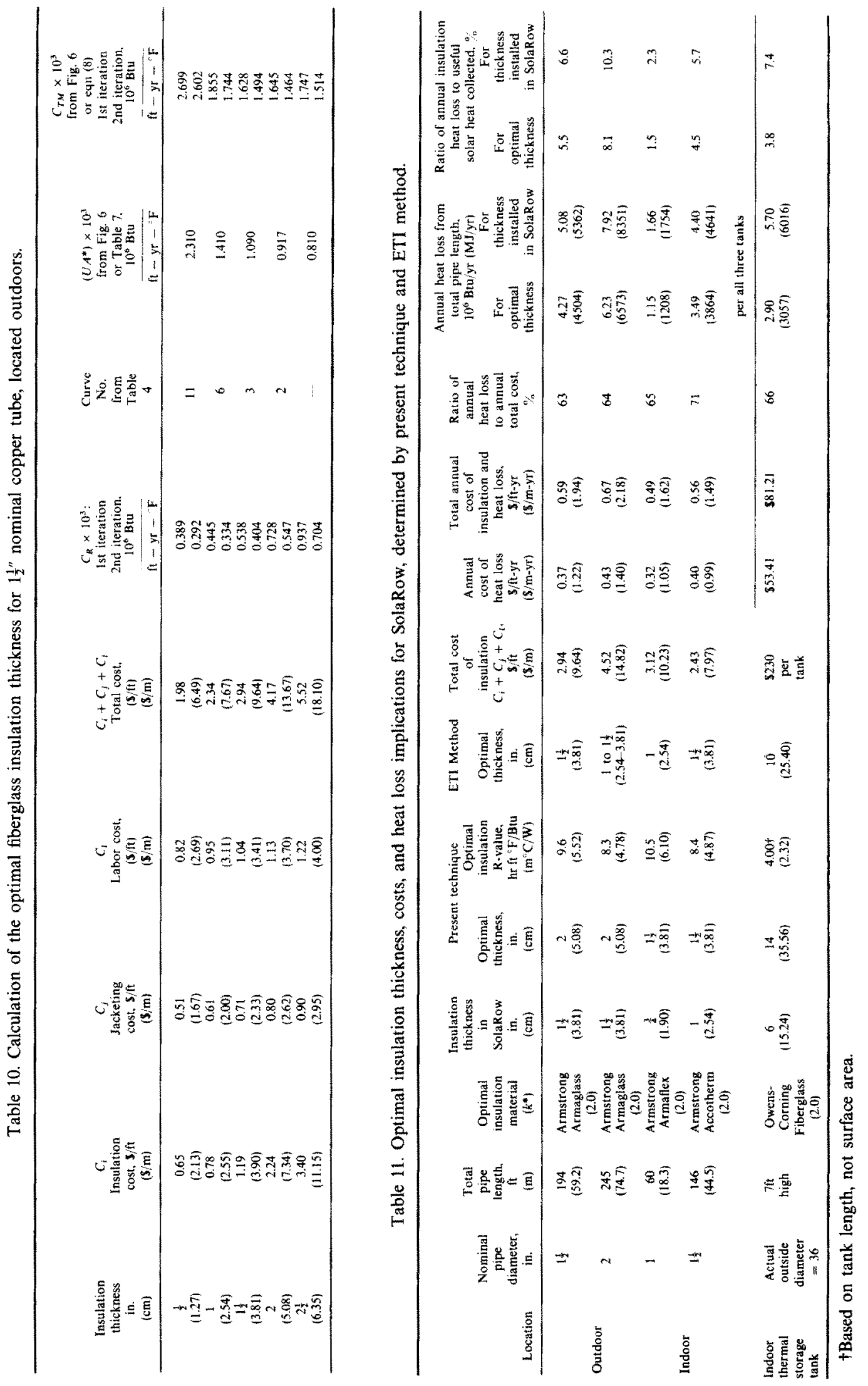


diminished. Specifically, in the present SolaRow system, the warm water is retained in the collectors and piping even in periods when the water does not circulate (see Section 6.1). If the water were drained back in to the thermal storage tanks when useful solar energy is not being collected, this residence time would be reduced significantly, giving $F \Delta T$ values of $15^{\circ} \mathrm{F}$ (instead of $24^{\circ} \mathrm{F}$ ) and $14^{\circ} \mathrm{F}$ (instead of $23^{\circ} \mathrm{F}$ ) for outdoor and indoor piping, respectively. With the present insulation, the heat losses would then be reduced to $22.8 \%$ (from the present loss value of $32.3 \%$ ).

It is noteworthy that an a-priori design for these new $F \Delta T$ values resulted in optimal insulation thickness equal to that calculated for the present $F \Delta T$ values in the cases of the $1 \frac{1}{2}^{\prime \prime}$ outdoor and indoor pipes, but one step smaller for the $2^{\prime \prime}$ outdoor and $1^{\prime \prime}$ indoor pipes. This is to be expected, since smaller $F \Delta T$ values lead to reduced heat losses, a fact which leads to an amount of insulation which is optimally smaller. Such a-priori design for the lower $F \Delta T$ values results in an insulation heat loss of $18.2 \%$, as compared to the $24.9 \%$ loss incurred through insulation optimized on the present $F \Delta T$ values. Any energy savings achieved by this method must, however, be judged against the disadvantages of frequent drain-down such as accelerated corrosion rates, increased pumping energy during startup, etc.

The cost of useful solar heat $\left(C_{s}\right.$, eqn (7)) influences the value of the optimal insulation through eqn (6). The value $\eta^{\dagger}$ in eqn (7) used in the present calculations did not take into account heat losses through the insulation. This initial assumption of zero heat losses through insulation is typical of most solar system design procedures. If insulation heat losses are significant, this assumption leads to wrong values of $\eta$, and hence of $C_{s}$ and of optimal insulation. Generally, the heat losses increase the cost of solar heat, thus economically justifying better insulation. An iterative method can be used in such cases:

(1) Obtain an $\eta$ value with the assumption of zero insulation heat loss.

(2) Determine the optimal insulation for this $\eta$.

(3) Calculate the insulation heat losses.

(4) Recalculate $\eta$ based on (3).

(5) Redetermine the optimal insulation for the new value of $\eta$.

(6) Recalculate the heat losses.

(7) Continue the above procedure (4)-(6) till the optimal insulation values for two successive iterations are equal.

The above described iterative procedure was conducted for calculating the optimal SolaRow insulation described in Table 11. It was found that only one iteration was required in addition to the initial calculation. No change resulted in the optimal insulation values except for the $1 \frac{1}{2}$ " outdoor pipe and the thermal storage tank. In these cases, the optimal insulation thickness increased by one step: from $1 \frac{1}{2}{ }^{\prime \prime}$ to $2^{\prime \prime}$, and from $12^{\prime \prime}$ to $14^{\prime \prime}$, respectively. The new value of $\eta$ is $(0.76)(0.47)=0.36$, and the corrected cost of solar heat is

$$
C_{s}=\$ 12.64 / 0.76=\$ 16.63 / 10^{6} \mathrm{Btu}
$$

The correct value of the total optimal insulation heat loss is $24 \%$ of the collected solar energy.

\subsection{The Proposed Method}

\section{CONCLUSIONS AND RECOMMENDATIONS}

The above described method for determining optimal insulation is oriented specifically to solar heating systems in their pertinent range of parameters, addressing the particular realistic thermal and economic aspects of this problem. The economic aspect of the problem is treated by a present-value life-cycle cost analysis. Nominal commercial pipe 
diameters and insulation thicknesses were used in the development of the method to allow more accurate results for practical applications. The method, assisted by the design graphs (Figs. 6, 7 and 8) or Tables (7, 8 and 9), is simple and straightforward to use. Apart from the value of the optimal insulation, the method also provides, when needed, additional information, such as amounts of energy lost through the insulation and annual costs of these energy losses. Total annual costs of insulation material, labor and lost heat, as well as the sensitivity of these costs to the proposed insulation, are also provided.

\subsection{Comparison to the ETI Method}

Although the $\mathrm{ETI}^{3}$ method for determining optimal insulation is well-accepted, the present method has a few advantages over it for solar heating systems: (1) it is oriented specifically to solar heating system problems and parameters; (2) it is based on a more comprehensive economic model than that of the ETI, which is particularly important here due to the extreme sensitivity of solar heating systems to economics; (3) it provides, when needed, more information about insulation system selection than just optimal thickness; (4) it addresses nominal commercial pipe and insulation size directly. It is slightly more time-consuming than the ETI nomographs, but given the data, it can provide optimal insulation values within 10-30 min of manual (or hand calculator) calculations.

As indicated in Table 11, the optimal insulation thicknesses obtained by this method are sometimes close to those determined by the ETI method for the same conditions and are either equal, or in most cases, one step higher. This difference most likely arises mainly from the application of the more comprehensive economic model in the present method.

\subsection{The Heat Transfer Sensitivity Analysis}

It was found that in the range of parameters pertinent to solar heating systems, three variables dominate heat loss through insulation. These are the nominal pipe diameter (or tank diameter), the thermal conductivity of the insulation, and the insulation thickness. Neglecting the influence of the other variables by keeping them at constant "base case" values results in errors of up to $\pm 14 \%$ for pipes and $\pm 19 \%$ for tanks. These errors were considered acceptable.

\subsection{Insulation for the SolaRow House and for Solar Heating Systems in General}

A major conclusion from the insulation analysis for SolaRow is that the loss of heat through the solar heating system's insulation is significant, amounting to $32 \%$ of the solar energy collected for the presently installed insulation, and $24 \%$ for optimal insulation. This arises mainly due to two reasons: (1) the existence of a large extent of insulated surface: $439 \mathrm{ft}$ of $1 \frac{1}{2}{ }^{\prime \prime}$ and $2^{\prime \prime}$ outdoor pipe, $206 \mathrm{ft}$ of $1^{\prime \prime}$ and $1 \frac{1}{2}$ " indoor pipe, and $240 \mathrm{ft}^{2}$ of thermal storage tank surface area; (2) the flow strategy which retains the water in the pipes after the system has stopped collecting useful solar energy, which thus permits heat loss during longer periods of time.

A major recommendation arising from this study is, therefore, that heat losses through insulation must receive careful quantitative consideration during the solar heating system's design process. Such losses could be reduced by minimizing: the length of piping, the surface of thermal storage tanks and the residence time of hot working fluid in the system in general, and in its oudoor portion in particular. For example, a reduction in total heat loss from $24 \%$ to $18 \%$ resulted from a change in the flow strategy in the SolaRow system by which the water would be allowed to drain into the thermal storage tanks when no useful energy is collected. An additional conclusion is that since the quantity $F\left(T_{f}-T_{a}\right)$ exhibits a large influence on the estimate of the heat loss (and thus on the determination of the optimal insulation thickness), further work is required to provide more accurate engineering design values of it as a function of system design and environmental variables. 
Another important observation is the high cost of insulation: $\$ 2944$ total (composed of $\$ 1666$ for materials and $\$ 1278$ for labor) for optimally insulating the SolaRow heating system, or close to $15 \%$ of the total system's cost. Again, reduction of the length of pipe and of the surface area for the thermal storage tanks would decrease these costs.

Acknowledgements--This study was supported in part by grants from the Pennsylvania Science and Engineering Foundation, the U.S. Department of Housing and Urban Development, and the Solar Heating and Cooling Research and Development Branch, Office of Conservation and Solar Applications, U.S. Departrnent of Energy.

9. NOMENCLATURE (Excluding symbols defined in Appendices)

$A=$ Heat transfer area.

$c_{p}=$ Specific heat, $\mathrm{Btu} / \mathrm{bm}^{\circ} \mathrm{F}$.

$C=$ Cost.

$C_{a}=$ First year cost of auxiliary energy delivered to storage, $\$ 110^{6}$ Btu.

$C_{i}=$ Base cost of the insulation material, including the cost of fitting and valve insulation prorated over the straight pipe length, $\$ / \mathrm{ft}$.

$C_{j}=$ Base cost of insulation jacketing, $\$ / \mathrm{ft}$.

$C_{l}=$ Base cost of insulation labor, $\$ / \mathrm{ft}$.

$C_{m}=$ Base cost of maintenance during the first year, $\$ / \mathrm{ft}$.

$C_{s}=$ Present value annual average cost of solar heat, defined in eqn (7), $\$ /\left(10^{6} \mathrm{Btu}-\mathrm{yr}\right)$.

$C_{R}=$ Cost ratio defined in eqn (9), (Btu/yr-ft $\left.{ }^{\circ} \mathrm{F}\right) \times 10^{-6}$.

$C_{T}=$ Total annual cost of insulation and lost energy defined in eqn (6).

$C_{T M}=$ Modified cost defined in eqn $(8),\left(B t u / f t-y r^{\circ} \mathrm{F}\right) \times 10^{-6}$.

$d=$ Diameter in.

$D=$ Nominal pipe diameter, in.

$E=$ Economic coefficients defined in eqns (B1)-(B4).

$f=$ Moody friction factor.

$f_{L}=$ Type of fluid heated in collectors.

$F=$ Annual usage factor $(0 \leq F \leq 1)$ of the insulated component. This is the annual fraction of time which the solar collection system (or storage tanks) loses heat.

$g=$ Gravitational constant.

$h=$ Heat transfer coefficient, Btu $/ \mathrm{hr}^{\circ} \mathrm{F} \mathrm{ft}^{2}$.

$k=$ Thermal conductivity, $\mathrm{Btu} / \mathrm{hr}{ }^{\circ} \mathrm{F} \mathrm{ft}$.

$k^{*}=k_{i}$ (British units)/0.010, nondimensional.

$l=$ Pipe length or tank height, $\mathrm{ft}$.

$L_{B}=$ Total annual space heating and domestic hot water load, $10^{6} \mathrm{Btu} / \mathrm{yr}$.

$M_{i}=$ Initial capital cost of solar heating system including all labor and materials, $\$$.

$M_{m}=$ First year maintenance cost of solar heating system, $\$$.

$M_{0}=$ First year operating cost of solar heating system, $\$$.

$M_{p}=$ Index indicating type of pipe.

$n=$ Period of economic analysis (usually life of system), years.

$\mathrm{Nu}=$ Nusselt Number.

$P=$ Pressure head, $\mathrm{ft}$

$\operatorname{Pr}=$ Prandtl Number

$Q=$ Heat flow rate, Btu/hr.

$Q^{\prime}=$ Total heat flow rate through tank surface, Btu/hr.

$r=$ Radius, in.

$R=$ Thermal resistance, $\mathrm{ft}^{\circ} \mathrm{F} \mathrm{hr} / \mathrm{Btu}$.

$\operatorname{Re}=$ Reynolds Number.

$t=$ Thickness, in.

$T=$ Temperature, ${ }^{\circ} \mathrm{F}$. 
$u=$ Error coefficient defined in eqn (20).

$U=$ Overall heat transfer coefficient.

$V=$ Wind velocity, miles per hour.

\section{Greek symbols}

$\beta=$ Volumetric expansivity ${ }^{\circ} \mathbf{F}^{-1}$.

$\gamma=$ Coefficient defined by eqn (A10).

$\Delta=$ Difference.

$\Delta T=T_{f}-T_{a},{ }^{\circ} \mathrm{F}\left({ }^{\circ} \mathrm{C}\right)$.

$\epsilon=$ Surface emissivity.

$\eta=$ Fraction of annual space heating and domestic hot water load contributed by solar energy.

$\theta=1$ or 0,1 corresponding to auxiliary heating of storage tank water directly, 0 corresponding to no direct auxiliary heating of water.

$\mu=$ Dynamic viscosity, $1 \mathrm{bm} / \mathrm{ft} \mathrm{sec}$.

$v=$ Kinematic viscosity $\mathrm{ft}^{2} / \mathrm{sec}$.

$\rho=$ Mass density, $\mathrm{lbm} / \mathrm{ft}^{3}$.

$\sigma=$ Stephan-Boltzman constant.

$\phi \equiv \Delta P / l=$ Pressure gradient in pipe, dimensionless.

\section{Subscripts}

$a=$ Air, auxiliary.

$a p=$ Average between the air and outside insulation surface.

$b=$ Tank bottom.

$f=$ Hot fluid.

$i=$ Inside, or insulation.

$j=$ Jacketing.

$l=$ Length of cylinder, or labor.

$m=$ Maintenance.

$o=$ Outside.

$p=$ Outside surface of insulation, or insulation.

$r=$ Radiative.

$t=$ Inside surface of pipe or tank wall, top of tank.

Superscripts

$'$ = Pertains to thermal storage tanks.

\section{REFERENCES}

1. J. J. Malloy, Thermal Insulation, Van Nostrand Reinhold Company, New York (1969).

2. ASHRAE Handbook of Fundamentals, Chapter 2, ASHRAE, 345 East 47 Street, New York, NY 10017 (1972).

3. York Research Corp., ETI-Economic Thickness for Industrial Insulation, Federal Energy Administration Conservation Paper No. 46, PB 259937, NTIS, U.S. Department of Commerce, Springfield, VA 22161, Aug. (1976).

4. P. J. Lunde, Solar Energy 19, 685 (1977).

5. J. A. Duffie and W. A. Beckman, Solar Energy Thermal Processes, J. Wiley, New York (1974).

6. N. Lior, J. Lepore and S. Shore, PROC. JOINT AS/ISES and SESC CONF., Winnipeg, Canada. Vol. 4, 36 Aug 15-20 (1976), AS/ISES, Inc., American Technological University, P.O. Box 1416. Killeen. TX 76541.

7. N. Lior, J. O'Leary and D. Edelman, PROC. AS/ISES CONF., 3-15, Orlando, FL, June 6-10 (1977), AS/ISES, Inc., American Technological University, P.O. Box 1416, Killeen, TX 76541.

8. B. Gebhart, Heat Transfer, McGraw Hill, New York (1977).

9. F. Kreith, Fundamentals of Heat Transfer, International Textbook Company, Scranton, PA (1973).

10. C. D. Barley and C. B. Wynn, Solar Energy 21, 4, 279 (1978). 


\section{APPENDIX A: DEVELOPMENT OF THE HEAT TRANSFER MODEL}

Consider the thermal circuit for the case of steady radial heat flow from a hot fluid through a composite circular wall of length If, assuming zero contact resistance between components as shown in Fig. 2 (neglecting contact resistance results in a conservative estimate of insulation thickness), with $2 r_{i}=d_{i}, \quad i=1,2,3$.

$$
\begin{aligned}
R_{1} & =1 / \pi d_{1} l h_{i} \\
R_{2} & =\ln \left(d_{2} / d_{1}\right) / 2 \pi l k_{p} \\
R_{3} & =\ln \left(d_{3} / d_{2}\right) / 2 \pi l k_{i} \\
R_{5} & =1 / \pi d_{3} l h_{p} \\
R_{6} & =1 / \pi d_{3} l h_{r} \\
h_{r} & =4 \epsilon \sigma\left[\left(T_{p}+T_{r}\right) / 2\right]^{3} .
\end{aligned}
$$

For $T_{r}=T_{a}$

$$
R_{4}=\frac{1}{1 / R_{5}+1 / R_{6}}
$$

and the expression for the rate of radial heat flow, per unit length of cylinder, is

$$
\begin{aligned}
Q_{l}=\left(T_{f}-T_{a}\right) / \sum_{i=1}^{4} R_{i}=\pi\left(T_{f}-T_{a}\right) /\left(\left(1 / d_{1} h_{i}\right)+\left[\ln \left(d_{2} / d_{1}\right) / 2 k_{p}\right]\right. \\
\left.+\left[\ln \left(d_{3} / d_{2}\right) / 2 k_{i}\right]+\left[1 / d_{3}\left(h_{o}+h_{r}\right)\right]\right\}=U A \Delta T
\end{aligned}
$$

where $\Delta T \equiv T_{f}-T_{a}$,

and $U$ is the overall heat transfer coefficient based on surface area $A$ and $A$ is the surface area selected per unit length of pipe.

Since

$$
d_{2} / d_{1}=1+\left(2 t_{p} / d_{1}\right) \text { and } d_{3} / d_{2}=1+\left(2 t_{i} / d_{2}\right)
$$

then

$$
d_{3}=\left[1+\left(2 t_{p} / d_{1}\right)+\left(2 t_{i} / d_{1}\right)\right] d_{1} \equiv \gamma d_{1}
$$

Thus,

$$
\begin{aligned}
U A= & \pi\left[\left(1 / d_{1} h_{i}\right)+\left\{\ln \left[1+\left(2 t_{p} / d_{1}\right)\right] / 2 k_{p}\right\}+\left\{\ln \left[1+\left(2 t_{i} / d_{1}+2 t_{p}\right)\right] / 2 k_{i}\right\}\right. \\
& \left.+\left[1 / \gamma d_{1}\left(h_{o}+h_{r}\right)\right]\right]^{-1}
\end{aligned}
$$

$\equiv$ rate of heat loss per unit of pipe length per unit of $\Delta T$. The value of $h_{i}$ for both indoor and outdoor piping can be evaluated for $10000 \leqslant \operatorname{Re} \leqslant 120000$ from the fully developed turbulent flow heat transfer correlation $^{8}$

$$
\mathrm{Nu}=0.023 \operatorname{Re}_{f}^{0.8} \operatorname{Pr}_{f}^{0.4}
$$

and the Fanning Equation ${ }^{8}$ with:

$$
f=0.184 \mathrm{Re}_{f}^{-0.20}
$$

as follows:

$$
h_{i}=0.31076 k_{f} d_{1}^{4 / 9} \phi^{1 / 3} \operatorname{Pr}_{f}^{0.4} v_{f}^{-8 / 9}\left(\mathrm{Btu} / \mathrm{hr} \mathrm{ft}^{2 \circ} \mathrm{F}\right)
$$

where $\phi \equiv \Delta P / l$, dimensionless pipe pressure gradient. The value of $h_{0}$ for outdoor piping (forced convection dominant) is determined by: ${ }^{9}$

$$
h_{o}=\left(k_{a} / \gamma d_{1}\right)\left(0.4 \operatorname{Re}_{a}^{0.5}+0.6 \operatorname{Re}_{a}^{0.67}\right) \operatorname{Pr}_{a}^{0.4}\left(\mu_{a} / \mu_{a p}\right)^{0.25}
$$

where

$$
\mathrm{Re}_{\mathrm{a}}=\gamma d_{1} V / v_{a}, \quad T_{a p}=\left(T_{a}+T_{p}\right) / 2
$$

For indoor piping where natural convection dominates:2

$$
h_{o}=0.27\left[\left(T_{p}-T_{a}\right) / \gamma d_{1}\right]^{1 / 4}
$$

Generally, the characteristic length used in the calculation of natural convection heat transfer coefficients is the diameter for horizontal cylinders and the height for vertical ones. A comparison of the optimal insulation thickness required when using the two lengths shows negligible differences for typical installations. For simplicity, all natural convection heat transfer coefficients were therefore determined in this study based on diameter. For the indoor thermal storage tanks, $h_{i}$ in eqn (A11) is evaluated from: ${ }^{2}$

$$
h_{i}=0.56 k_{f}\left[\rho_{f} \beta_{f} c_{p f} g\left(T_{f}-T_{t}\right)\left(d_{1} v_{f} k_{f}\right)^{-1}\right]^{0.25}
$$

†Other symbols are defined in Section 9. 
For vertical tanks with legs, $h_{o, t}$ and $h_{i, t}$ in eqn (5) are evaluated from eqn (A17) with $\gamma d_{t}$ replaced by $d_{1}$, and eqn (A18), respectively.

Also 9

$$
h_{i, b}=k_{f} / d_{1} \text { and } h_{o, b}=0.12\left[\left(T_{p}-T_{a}\right) / d_{1}\right]^{1 / 4}
$$

\section{APPENDIX B: EQUATIONS FOR CONVERTING CASH FLOWS TO PRESENT VALUES}

The terms $\mathrm{E}$ used in Section 2.2 to convert cash flows to present-values (cf. Barley and Wynn ${ }^{10}$ ) are defined as follows:

$$
\begin{array}{r}
E_{1(j)}=\alpha_{(j)}-\beta_{(j)}-\sigma_{(j)}[(1+g) /(1+d)]^{n}+\left[(1-t) p_{(j)}+h_{(j)}\right] P\left(d, g, n_{(j)}\right) \\
+\left(1-\alpha_{(j)}\right)\left\{(1-t)\left[P\left(d, 0, m_{(j)}\right) / P\left(i_{(j)}, 0, m_{(j)}\right)\right]\right. \\
+\left[P\left(d, i_{(j)}, m_{(j)} / P\left(0, i_{(j)}, m_{(j)}\right]\right\}-\mathrm{B}\right. \\
E_{2(j)}=\left(1-t_{1}\right) P\left(d, r_{m(j)}, n\right) \\
E_{3}=\left(1-t_{1}\right) P\left(d, r_{o}, n\right) \\
E_{4}=\left(1-t_{1}\right) P\left(d, r_{f}, n\right)
\end{array}
$$

where

The index $j \equiv 1$ for the insulation or

$j \equiv 2$ for the complete solar system.

$\alpha_{(j)}=$ Downpayment fraction of first cost.

$\beta_{(j)}=$ Investment tax credit fraction, if applicable.

$\sigma_{(j)}=$ Fractional salvage value at end of equipment life.

$g=$ Annual general inflation rate, (per cent/100).

$d=$ Annual discount rate, which could be chosen as either that for mere inflation, for an opportunity cost of money, or for a required return on investment, (per cent $/ 100$ ).

$t=$ Annual incremental income tax rate (only applicable in business applications, where the capital expenses are income tax deductible, otherwise $t=0$ ), (per cent $/ 100$ ).

$t_{1}=$ Same as $t$, but only applicable if maintenance, operating and fuel expenses are tax deductible, otherwise $t_{1}=0$.

$p=$ Actual annual property tax rate, (per cent $/ 100$ )

$h=-$ Annual insurance cost as a fraction of the first cost.

$$
P(d, r, n) \equiv\left[(1+d)^{n}-(1+r)^{n}\right] /(1+d)^{n}(d-r) \text { for } d \neq r
$$

and

$$
P(d, r, n) \equiv n /(1+r) \text { for } d=r
$$

$n=$ Period of economic analysis (usually life of system), years.

$i_{(j)}=$ Annual interest rate on loan or mortgage, (per cent $/ 100$ ).

$m_{(j)}=$ Period of loan or mortgage, years.

$B=$ Cumulative present worth of depreciation tax credits per dollar invested: with straight line depreciation:

$$
B_{\text {sL }}=t(1-\sigma) P(d, 0, k) / k
$$

with Declining Balance:

$$
B_{D B}=t \delta P(d,-\delta / k, k) / k
$$

and with Sum of Years Digits

$$
B_{\text {SOYD }}=2 t(1-\sigma)\left[P\left(d_{(j)}, 0, k\right)+\{[k-1-P(d, 0, k-1] / d\}] / k(k+1)\right.
$$

where

$k=$ Depreciation lifetime.

$\delta=$ Declining balance multiplier

$r_{m(j)}=$ Annual fractional rate of increase in maintenance expense.

$r_{o}=$ Annual fractional rate of increase in operating expense of solar system.

$r_{f}=$ Annual fractional rate of increase in auxiliary fuel expense.

To demonstrate the use of these equations, they are applied in determining the optimal insulation for the SolaRow house, with the specific data listed in Section 6.1 of this paper. Using eqn (B5): 


$$
\begin{aligned}
& P(d, g, n)=P(0.07,0.06,25)=\frac{(1+0.07)^{25}-(1+0.06)^{25}}{(1+0.07)^{25}(0.07-0.06)}=20.9226 \\
& P(d, 0, m)=P(0.07,0,20)=\frac{(1+0.07)^{20}-1}{(1+0.07)^{20} 0.07}=10.5940 \\
& P(i, 0, m)=P(0.09,0,20)=\frac{(1+0.09)^{20}-1}{(1+0.09)^{20}(0.09)}=9.1285 \\
& P(d, i, m)=P(0.07,0.09,20)=\frac{(1+0.07)^{20}-(1+0.09)^{20}}{(1+0.07)^{20}(0.07-0.09)}=22.4143 \\
& P(0, i, m)=P(0,0.09,20)=\frac{1-(1+0.09)^{20}}{1(0-0.09)}=51.1601 .
\end{aligned}
$$

From eqn (B1) and the above:

$$
\begin{aligned}
E_{1\{1\}}=E_{1\{2\}}=0.2-0-0+[(1-0.18) 0.005 & +0.003] 20.9226 \\
& +(1-0.2)\left[(1-0.18) \frac{10.5940}{9.1285}+0.18 \frac{22.4143}{51.1601}\right]-0=1.173 .
\end{aligned}
$$

From eqn (B2)

$$
E_{2(1)}=E_{2(2)}=P\left(d, r_{m}, n\right)=P(0.07,0.06,25)=20.9226
$$

From eqn (B3)

$$
E_{3}=P\left(d, r_{0}, n\right)=P(0.07,0.06,25)=20.9226 \text {. }
$$

